\title{
Spatial distribution of symbiont-bearing dinoflagellates in the Indian Ocean in relation to oceanographic regimes
}

\author{
Woraporn Tarangkoon ${ }^{1,2}$, Gert Hansen ${ }^{3}$, Per Juel Hansen ${ }^{1, *}$ \\ ${ }^{1}$ Marine Biological Laboratory, Strandpromenaden 5, 3000 Helsingør, Denmark \\ ${ }^{2}$ Faculty of Science and Fisheries Technology, Rajamangala University of Technology Srivijaya, 92150 Trang, Thailand \\ ${ }^{3}$ Phycology Laboratory, Ø. Farimagsgade 2D, 1353 Copenhagen, Denmark
}

\begin{abstract}
The spatial distribution of symbiont-bearing dinoflagellates was investigated during a cruise from Cape Town, South Africa to Broome, Australia. Endo- and ectosymbionts were only found in the order Dinophysiales. The genera Ornithocercus, Histioneis, Parahistioneis and Citharistes had cyanobacteria as ectosymbionts, while the genera Amphisolenia and Triposolenia contained both intact cyanobacterial and eukaryotic endosymbionts. The symbiont-bearing dinoflagellates were mainly found in the upper $100 \mathrm{~m}$ of the water column. Their distribution was restricted to water temperatures exceeding $16.5^{\circ} \mathrm{C}$, and the highest species diversity and cell concentrations were found at temperatures around 20 to $30^{\circ} \mathrm{C}$. The symbiont-bearing dinoflagellates were always associated with water masses with low nutrient (N-limited) and chl a concentrations. Special attention was given to the ectosymbiont-bearing dinoflagellates. Under light microscopy, some of the food vacuoles of Ornithocercus spp. resembled ectosymbionts in size, shape and colour. Transmission electron microscopy of $O$. magnificus and $O$. quadratus revealed the presence of a peduncle and many rhabdosomes; both may serve in prey capture. Also, numerous food vacuoles were present, but their content was generally too degraded for a proper identification of prey type. However, occasionally remnants of eukaryotes were observed, indicating that Ornithocercus spp. may feed on ciliates. Thus, our data suggest that the ectosymbiont-bearing dinoflagellates use a multi-resource strategy (photosynthesis and phagotrophy) to cope with a low-nutrient environment.
\end{abstract}

KEY WORDS: Symbionts · Ornithocercus $\cdot$ Amphisolenia $\cdot$ Histioneis $\cdot$ Dinophysoids $\cdot$ Dinoflagellates Indian Ocean · Galathea 3

\section{INTRODUCTION}

The world's oceans are estimated to contribute around half of global net primary productivity, with approximately one-quarter of this attributed to oligotrophic regions (Field et al. 1998). These oligotrophic areas are dominated by small primary producers (Li 1995, Maranon et al. 2003), in particular cyanobacteria. However, some of these small primary producers also form symbioses with other organisms. Symbiosis among protists varies from a relatively loose attachment of one species to another (ectosymbiosis) to an intimate endocytic relationship with one symbiont living within the protoplasm of the other (Norris 1967).

Heterotrophic dinoflagellates of the order Dinophysiales, e.g. the genera Histioneis, Ornithocercus, Parahistioneis, Amphisolenia and Triposolenia are known to form symbioses with cyanobacteria and eukaryotes (Kofoid \& Skogsberg 1928, Lucas 1991, Gordon et al. 1994, Janson et al. 1995, Jyothibabu et al. 2006). These genera contain very conspicuous species, with cell lengths of up to several hundreds of micrometres. Usually the symbionts are ectosymbionts, either associated with the cingular groove or found in 
special cavities of the dinoflagellate cell body (Norris 1967), but in some cases the symbionts are intracellular, such as the symbionts of Amphisolenia spp. (Lucas 1991).

Symbiont-bearing dinoflagellates (here and throughout the text meaning species of Dinophysiales) have been found in tropical to subtropical regions, and they occur almost exclusively in oligotrophic oceans such as the Pacific (Gómez 2005, Foster et al. 2006a,b), Indian (Wood 1963a, Taylor 1976) and Atlantic Oceans (Foster et al. 2006a,b). Although they probably have a wide distribution in subtropical and tropical seas, very few quantitative data are available on their distribution in time and space. Their apparent restriction to nitrogenlimited oligotrophic tropical oceans have led some authors to suggest that the photosynthetic symbionts are able to fix $\mathrm{N}_{2}$, and the host may benefit from this (Gordon et al. 1994, Jyothibabu et al. 2006). Because only bacteria are known to fix $\mathrm{N}_{2}$, this explanation only holds true for those species which have cyanobacterial symbionts, unless of course $\mathrm{N}_{2}$-fixing heterotrophic bacteria are involved (Farnelid \& Riemann 2008). Cyanobacterial symbionts have been found in species belonging to the genera Amphisolenia, Histioneis, Ornithocercus and Parahistioneis. However, nitrogenase activity (seen with immunolabelling-transmission electron microscopy [TEM] using nitrogenase antisera) has so far only been found in one type of cyanobacteria, a symbiont of $H$. depressa (Foster et al. 2006a).

It is still unknown whether and how the symbiontbearing dinoflagellates utilise photosynthetic products from the cyanobacterial symbionts. Do they utilise dissolved organic matter leaking from the cyanobacteria or do they ingest some of their symbionts and thereby gain organic matter? Food vacuoles have been observed inside the dinoflagellate hosts (Lucas 1991). In the case of Ornithocercus magnificus, Histioneis dolon and Parahistioneis para, food vacuoles and remnants of cyanobacterial symbionts have been observed inside their food vacuoles (Lucas 1991).

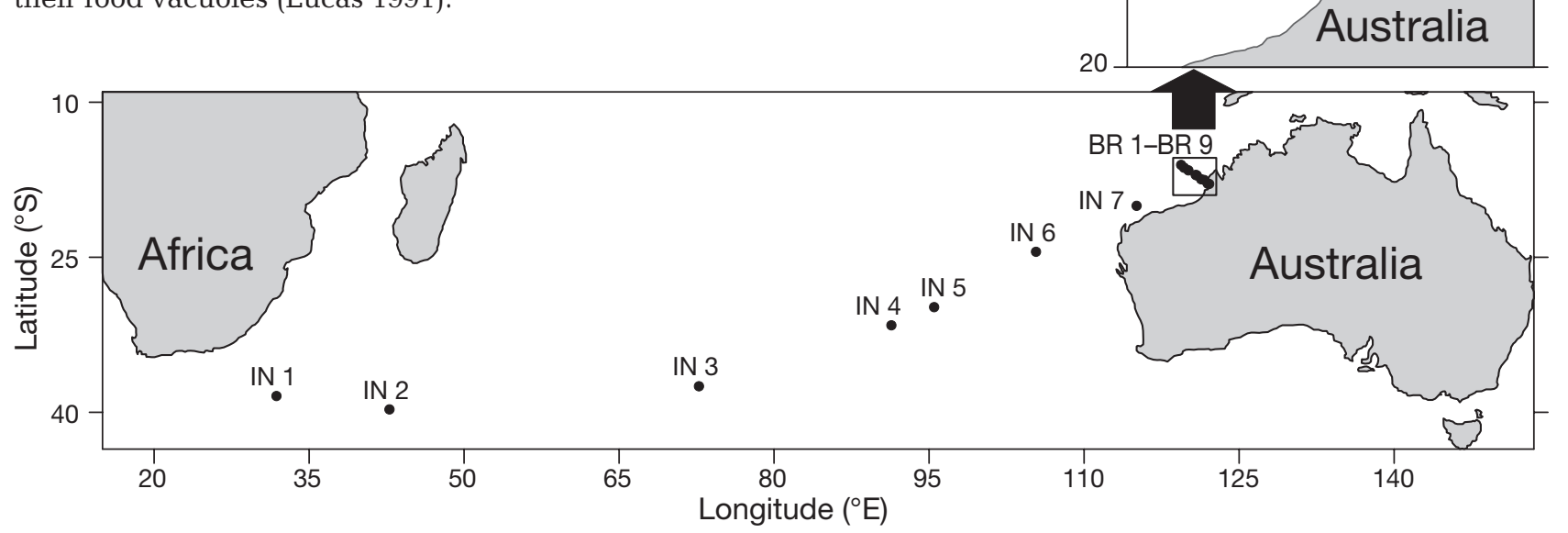

Fig. 1. Location of sampling stations along the Indian Ocean (Stns IN1 to IN7) and Broome (Stns BR1 to BR9) transects

The aim of this investigation was to (1) investigate the distribution of symbiont-bearing dinoflagellates across the southern Indian Ocean in relation to oceanographic regimes, qualitatively and quantitatively, and (2) examine Ornithocercus spp. under light microscopy and TEM to study food vacuole content and feeding apparatus and search for possible preycapture cell organelles to understand their role in the marine pelagic ecosystem.

\section{MATERIALS AND METHODS}

Sample location and environmental measurements. Samples were taken from aboard the Danish Navy surveillance frigate 'F359 Vædderen' during Leg 7 of the 3rd Danish Galathea expeditions around the world during 2006-2007. Leg 7 went from Cape Town in South Africa to Broome in northwestern Australia in the period 18 October to 16 November 2006. We present data from 21 stations across the Indian Ocean and along a transect perpendicular to Broome in northwestern Australia (Fig. 1, Table 1). The Seabird 9/11 CTD and a light sensor mounted on a rosette equipped with twelve 301 Niskin bottles were used to measure oceanographic parameters, including irradiance, salinity and temperature. The vertical CTD profiles were repeated thrice to a depth of at least $400 \mathrm{~m}$ along the

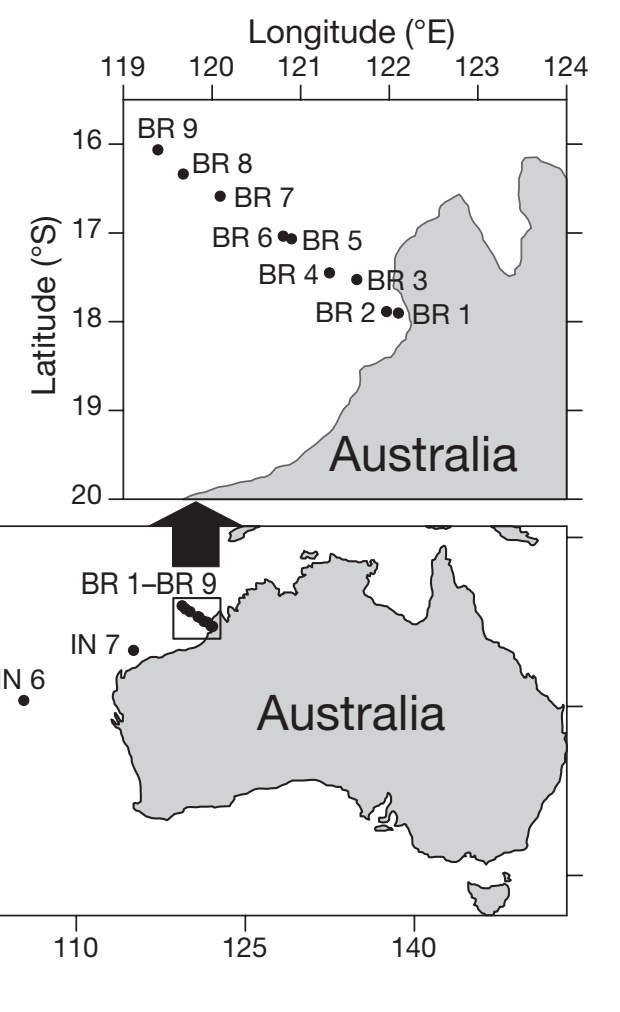


Table 1. Position and maximum depth of sampling stations. nd: no data

\begin{tabular}{|lccc|}
\hline Stn & $\begin{array}{c}\text { Latitude } \\
\left({ }^{\circ} \mathrm{S}\right)\end{array}$ & $\begin{array}{c}\text { Longitude } \\
\left({ }^{\circ} \mathrm{E}\right)\end{array}$ & $\begin{array}{c}\text { Maximum } \\
\text { depth }(\mathrm{m})\end{array}$ \\
\hline Indian Ocean & & & \\
IN1 & $38^{\circ} 29^{\prime}$ & $31^{\circ} 43^{\prime}$ & 4002 \\
IN2 & $39^{\circ} 33^{\prime}$ & $42^{\circ} 46^{\prime}$ & 2430 \\
IN3 & $37^{\circ} 16^{\prime}$ & $72^{\circ} 30^{\prime}$ & nd \\
IN4 & $31^{\circ} 24^{\prime}$ & $91^{\circ} 11^{\prime}$ & 4355 \\
IN5 & $29^{\circ} 35^{\prime}$ & $95^{\circ} 15^{\prime}$ & 2747 \\
IN6 & $24^{\circ} 27^{\prime}$ & $105^{\circ} 14^{\prime}$ & 5303 \\
IN7 & $19^{\circ} 46^{\prime}$ & $114^{\circ} 51^{\prime}$ & 1381 \\
Broome & & & \\
BR1 & $17^{\circ} 46^{\prime}$ & $121^{\circ} 52^{\prime}$ & 39 \\
BR2 & $17^{\circ} 41^{\prime}$ & $121^{\circ} 44^{\prime}$ & 103 \\
BR3 & $17^{\circ} 28^{\prime}$ & $121^{\circ} 27^{\prime}$ & 195 \\
BR4 & $17^{\circ} 17^{\prime}$ & $121^{\circ} 08^{\prime}$ & 198 \\
BR5 & $17^{\circ} 03^{\prime}$ & $120^{\circ} 49^{\prime}$ & 170 \\
BR6 & $16^{\circ} 50^{\prime}$ & $120^{\circ} 34^{\prime}$ & 358 \\
BR7 & $16^{\circ} 26^{\prime}$ & $119^{\circ} 56^{\prime}$ & 675 \\
BR8 & $16^{\circ} 15^{\prime}$ & $119^{\circ} 38^{\prime}$ & 1142 \\
BR9 & $16^{\circ} 01^{\prime}$ & $119^{\circ} 19^{\prime}$ & 1852 \\
\hline
\end{tabular}

Indian Ocean transect and lower depth in some stations along the Broome transect depending on their maximum depth at each station, starting at 08:00 $\mathrm{h}$, with downward cast used to describe the water column structure and water samples taken during each upward cast. Nutrients and chlorophyll a (chl a) concentrations were determined from the first CTD cast at 08:00 h.

Light: Light attenuation was estimated from photosynthetically active radiation (PAR) data collected with the CTD measured relative to a surface PAR sensor (Biospherical QSR). Data were fitted to a 2-phase exponential decay equation:

$E(z)=$ ref $\times \exp (-K \times z)$ for depth $\leq z_{\text {shift }}$

$E(z)=\operatorname{ref} \times \exp \left(-K_{\mathrm{d} 1} \times z_{\text {shift }}\right) \times \exp \left(-K_{\mathrm{d} 2} \times\left(z-Z_{\text {shift }}\right)\right.$

where $E(z)$ is irradiance at the depth $z, K_{\boldsymbol{d} 1}$ and $K_{\boldsymbol{d} 2}$ the diffuse attenuation coefficients above and below the depth $z_{\text {shift }}$, respectively, and ref is reflection from the surface. All 4 parameters ( $r e f, K_{\mathbf{d} 1}, K_{\mathbf{d} 2}, Z_{\text {shift }}$ ) were fitted to data from each CTD cast in 1 step using SAS software (1990) after data corrupted by wave actions and instrument failure were omitted.

Nutrients: Samples of $33 \mathrm{ml}$ for determination of nutrient concentration were taken directly from the water bottle and frozen immediately after sampling. The nutrient concentrations were later analysed at the National Environmental Research Institute (NERI) in an automatic nutrient analyser (Dansk Havteknik) following Grasshoff (1976). Nutrient samples were analysed with a detection limit of $0.06,0.1,0.04,0.3$ and $0.2 \mu \mathrm{M}$ for phosphorus, nitrate, nitrite, ammonia and silicate, respectively.
Pigments: Chl $a$ and phaeopigments (phaeo) concentrations (total and $>10 \mu \mathrm{m}$ ) were measured on 500 and $1000 \mathrm{ml}$ triplicate samples filtered onto Whatman GF/F and $10 \mu \mathrm{m}$ filters respectively. The filters were extracted overnight in $5 \mathrm{ml}$ of $96 \%$ ethanol (Jespersen \& Christoffersen 1987) and measured before and after acid addition ( 3 drops of $1 \mathrm{~N} \mathrm{HCl}$ ) on a Turner Designs Model 700 fluorometer calibrated against a pure chl a standard. Chl a values were converted to carbon assuming a C:chl a ratio of 50 .

The oceanographic parameters, including irradiance, salinity, temperature, nutrient concentrations and chl a concentration, are reported in detail in A. W. Visser et al. (unpubl.), but used here in the analysis of the observed distribution patterns of symbiont-bearing dinoflagellates.

Identification and enumeration of symbiont-bearing dinoflagellates. Water samples (10 1) were collected from each discrete depth (4 to 7 depths) within the upper $400 \mathrm{~m}$ using 301 Niskin bottles arranged on a CTD rosette. Then water samples were immediately concentrated using $20 \mu \mathrm{m}$ mesh-size plankton net in the laboratory. The concentrated samples were preserved in $1 \%$ neutral Lugol's solution and subsequently filtered onto a $0.2 \mu \mathrm{m}$ black polycarbonate filter. When approximately $1 \mathrm{ml}$ sample was left in the chimney, $0.2 \mathrm{ml}$ Calcofluor White M2R (Polysciences; $10 \mathrm{mg} \mathrm{l}^{-1}$ dissolved in distilled water) was added, and the filtration was continued after 5 min until the filter was dry. The dry filter was mounted on immersion oil (Type DF, Cargille Laboratories) on a slide. Another drop of immersion oil was then placed on the filter and a cover glass mounted on the top of the immersion oil (Andersen \& Kristensen 1995). This sample slide was used for species identification and enumeration of symbiontbearing dinoflagellates by epifluorescence microscopy, using UV excitation (330 to $385 \mathrm{~nm}$ ) and an appropriate emission filter (420 nm) (using an Olympus BX50 microscope fitted with Olympus DP70 digital camera). Dinoflagellates were identified using Kofoid (1906, 1907), Kofoid \& Michener (1911), Kofoid \& Skogsberg (1928), Wood (1954, 1963a,b), Abé (1967) and Taylor (1976). Live plankton samples were collected using a $20 \mu \mathrm{m}$ mesh-size plankton net and vertical hauls from about $70 \mathrm{~m}$ depth to the surface. Samples were examined and selected cells were photographed shortly after sampling using an Olympus BX51 microscope with a Soft-Imaging ColorView III digital camera.

Correlation between symbiont-bearing dinoflagellates and selected environmental variables were investigated using Pearson's correlation analysis (SPSS Statistics 17.0 software). Prior to the analysis, normality (Kolmogorov-Smirnov test) and homogeneity (Levene's test) were tested and when necessary, the data were $\log (\mathrm{x}+1)$-transformed. 
Fine structure of Ornithocercus magnificus and O. quadratus. Cells (Ornithocercus magnificus and $O$. quadratus) for TEM observations were single cells isolated from live plankton samples collected 31 October 2007 at Stn IN5 and fixed in 2\% glutaraldehyde in $0.05 \mathrm{M}$ Na-cacodylate buffer with $0.25 \mathrm{M}$ sucrose (final concentrations) for $1.5 \mathrm{~h}$. After a brief rinse in sterile filtered seawater, cells were individually transferred to a small drop of warm $1.5 \%$ agar made up in seawater. The hardened agar drops were then washed in $0.1 \mathrm{M}$ Na-cacodylate buffer with different sucrose concentrations: $0.25 \mathrm{M}$ and $0.125 \mathrm{M}$ sucrose and lastly in straight buffer. The drops were transferred every $20 \mathrm{~min}$ and finally fixed for $1 \mathrm{~h}$ in $2 \% \mathrm{OsO}_{4}$. After a brief rinse in buffer, cells were dehydrated in a graded ethanol series and embedded in Spurr's resin via propylene oxide. The material was sectioned on a Reichert Ultracut E ultramicrotome using a diamond knife, and the sections were collected on slot grids and placed on Formvar film. After staining in uranyl acetate and lead citrate, sections were examined in a JEOL JEM-1010 electron microscope operated at $80 \mathrm{kV}$. Micrographs were taken using a GATAN 792 digital camera. A total of 9 cells were examined ( 7 O. magnificus and $2 O$. quadratus).
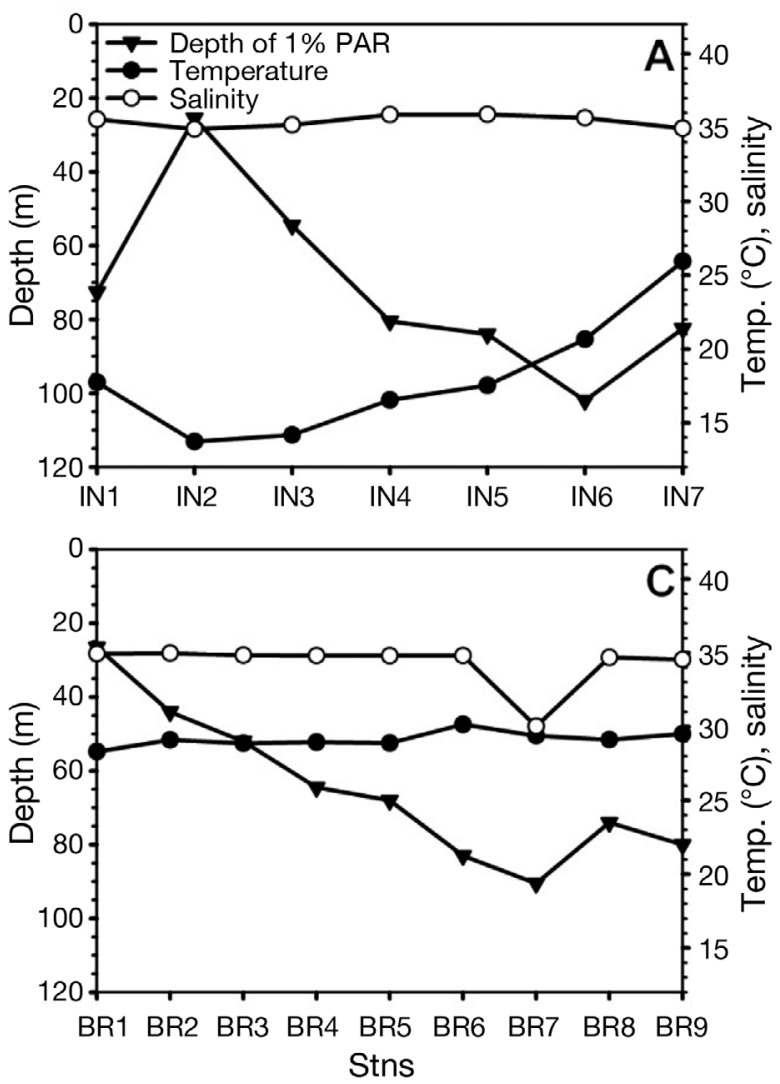

\section{RESULTS}

\section{Hydrography and chlorophyll a}

Indian Ocean transect (Stns IN1 to IN7)

The temperature in the surface waters ranged from $13.7^{\circ} \mathrm{C}$ at the southernmost station, IN2, on the South African coast, to $25.9^{\circ} \mathrm{C}$ at Stn IN7 on the west coast of Australia (Fig. 2A). Surface salinity was in the range of 34.9 to 35.9 . The euphotic zone (i.e. irradiance above $1 \%$ of that at the surface) ranged between 25.5 and $102 \mathrm{~m}$ along the Indian Ocean transect (Fig. 2A). Inorganic nitrogen concentration variability in surface water was large, from 3.1 to $3.9 \mu \mathrm{mol} \mathrm{l}^{-1}$ at Stns IN2 and IN3 to $<0.1 \mu \mathrm{mol} \mathrm{l}^{-1}$ at Stns IN4 to IN7, indicating a likely nitrogen limitation of the surface waters in this area $(0$ to $10 \mathrm{~m})$. Phosphate concentrations ranged from 0.1 to $0.4 \mu \mathrm{mol} \mathrm{l}^{-1}$. Similarly, maximum concentrations of phosphate were found at Stns IN2 and IN3 $\left(0.4 \mu \mathrm{mol} \mathrm{l}^{-1}\right)$, while much lower concentrations $\left(<0.10 \mu \mathrm{mol} \mathrm{l^{-1 }}\right)$ were found at Stns IN6 and IN7. The N:P ratio in surface water was between 0.13 and 13, lower than the Redfield ratio of $16: 1$, further supporting the idea of nitrogen as the
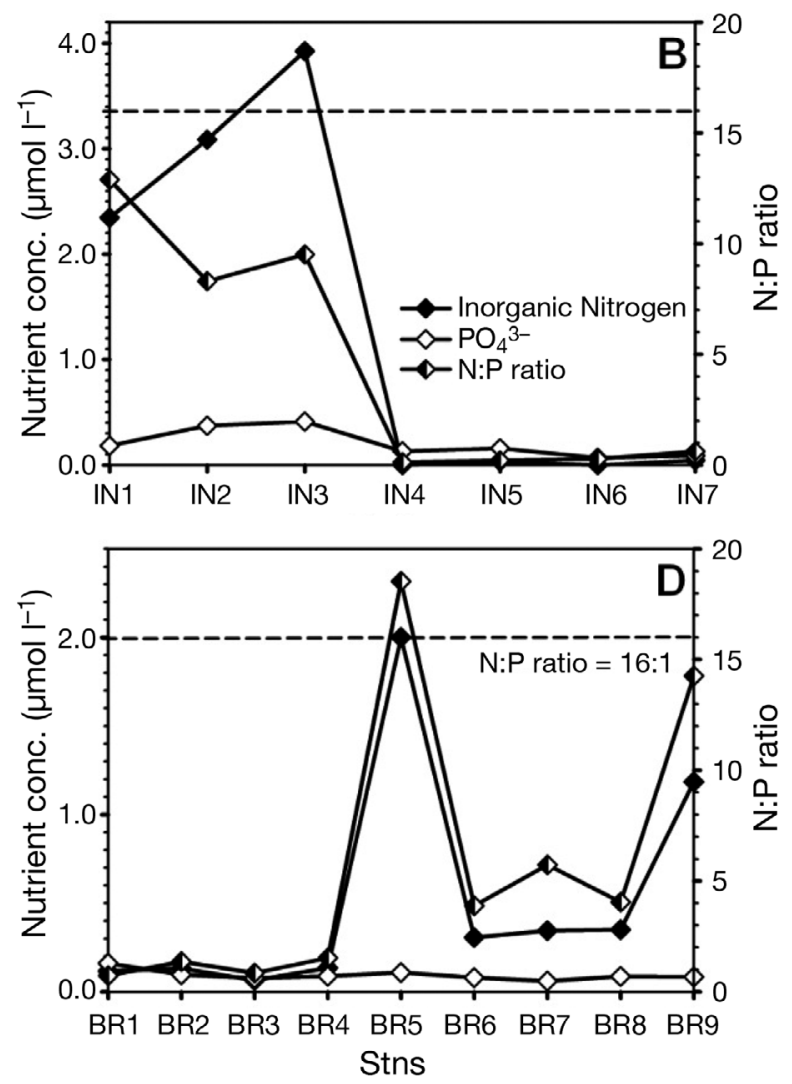

Fig. 2. Spatial distribution of environmental parameters (temperature, salinity, depth of $1 \%$ photosynthetically active radiation [PAR]) and nutrients (inorganic nitrogen, $\mathrm{PO}_{4}{ }^{3-}, \mathrm{N}: \mathrm{P}$ ratio) in surface waters $(10 \mathrm{~m})$ at each station in the $(\mathrm{A}, \mathrm{B})$ Indian Ocean and $(C, D)$ Broome transects. Dashed line: Redfield ratio of $C: N=16$. Note the different scales for nutrient concentration in (B) \& (D) 

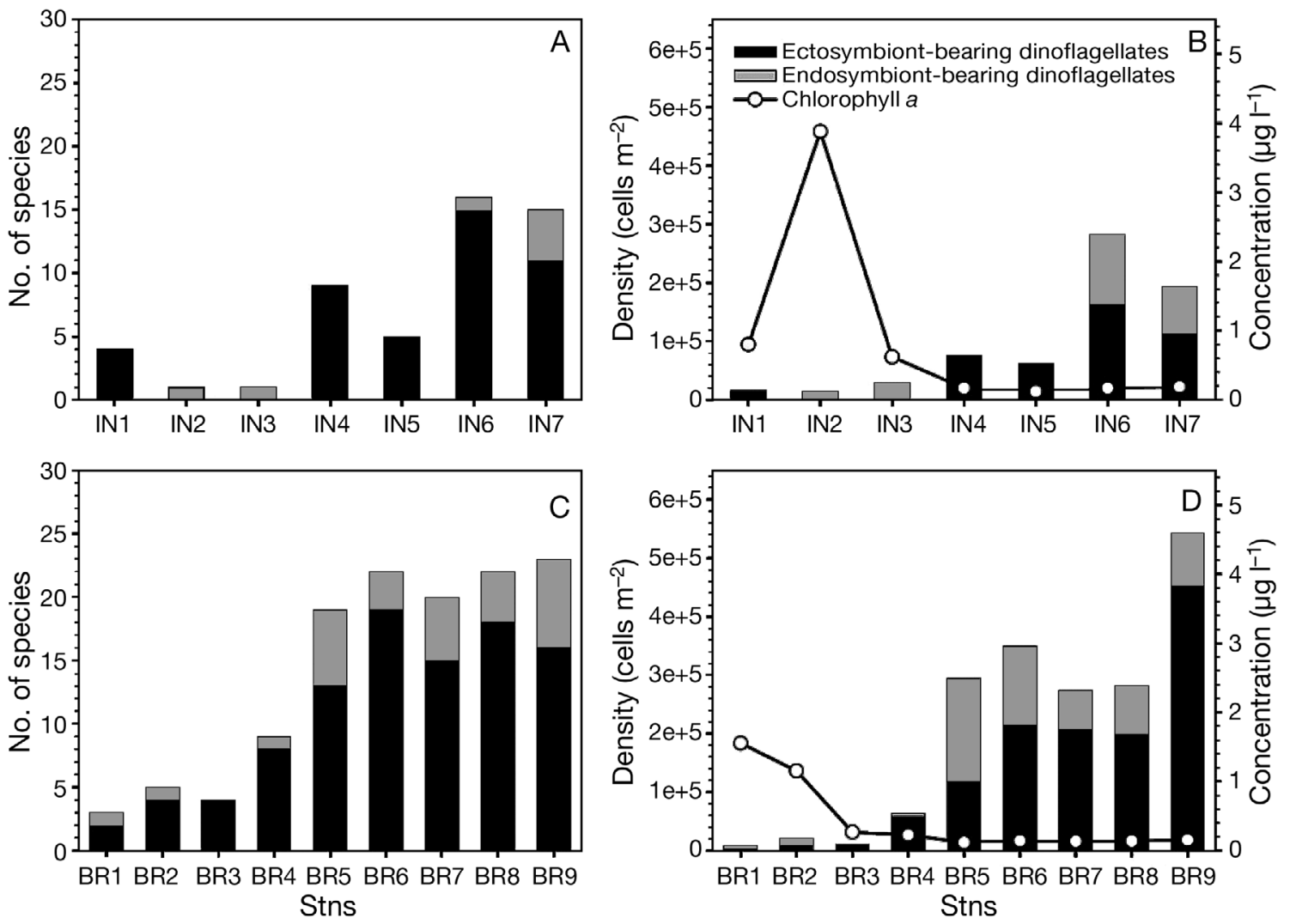

Fig. 3. $(A, C)$ Number of species of symbiont-bearing dinoflagellates and $(B, D)$ integrated densities of symbiont-bearing dinoflagellates and chl a concentration in the $(A, B)$ Indian Ocean and $(C, D)$ Broome transects

limiting nutrient (Fig. 2B). Chl a concentrations in surface water along this transect ranged from 0.1 to $3.9 \mu \mathrm{g} \mathrm{chl} \mathrm{a} \mathrm{l}^{-1}$; the highest concentration was found at the coastal stations (Fig. 3B).

\section{Broome transect (Stns BR1 to BR9)}

Surface temperatures varied from 28.3 to $30.1^{\circ} \mathrm{C}$, while salinity ranged from 34.5 to 35 , except for Stn BR7, where the salinity was only 30.0 (Fig. 2C). The depth of the euphotic zone varied from $27 \mathrm{~m}$ close to the coast to $91 \mathrm{~m}$ offshore (Fig. 2C). The concentration

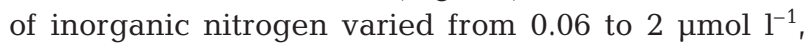
with the highest concentrations at Stns BR5 and BR9 (Fig. 2D) in the upper $10 \mathrm{~m}$. Phosphate concentrations varied from 0.06 to $0.16 \mu \mathrm{mol} \mathrm{l}^{-1}$ in the upper $10 \mathrm{~m}$, with the highest concentration found at the coastal station (Stn BR1). The N:P ratio in surface water was between 0.7 to 5.7 with the exception of very high $\mathrm{N}: \mathrm{P}$ ratios of 14.3 and 18.5 at Stns BR9 and BR5, respectively. Chl a concentrations in surface waters along this cruise transect varied between 0.1 and $1.6 \mu \mathrm{g} \mathrm{chl} \mathrm{a} \mathrm{l}^{-1}$. The highest chl a concentrations were found at the coastal stations (Fig. 3D).

\section{Species diversity}

A total of 45 species of symbiont-bearing dinoflagellates were found on this cruise. Most of these (33 species) had cyanobacterial ectosymbionts and belonged to 4 genera of family Dinophysiaceae: Ornithocercus, Citharistes, Histioneis and Parahistioneis. The remaining 12 species had eukaryotic or prokaryotic endosymbionts and belonged to the genera Amphisolenia and Triposolenia within the family Amphisoleniaceae (Table 2).

The largest diversity of symbiont-bearing dinoflagellates was found within the genera Histioneis and Amphisolenia, with 23 and 10 species observed, respectively (Table 2). The most common ectosymbiont-bearing dinoflagellate species were $H$. striata Kofoid \& Michener 1911, and Ornithocercus heteroporus Kofoid 1907, both found at 12 stations. Other common species were O. magnificus Stein, 1883 and H. depressa Schiller 1933, found at 11 and 10 stations, respectively. Many species of ectosymbiont-bearing dinoflagellates were rare, however, and only encountered once at a single station, like $H$. biremis Stein 1883, H. dolon Murray \& Whitting 1899, H. panda Kofoid \& Michener 1911, H. paulseni Kofoid 1907, H. 
Table 2. Abundance of symbiont-bearing dinoflagellates in the Indian Ocean (both transects) and the surface temperature range of their occurrence

\begin{tabular}{|c|c|c|}
\hline Species & $\begin{array}{l}\text { Cell density } \\
\left(\text { cells } 1^{-1}\right)\end{array}$ & $\begin{array}{c}\text { Surface } \\
\text { temperature }\left({ }^{\circ} \mathrm{C}\right)\end{array}$ \\
\hline \multicolumn{3}{|l|}{ Ectosymbiont-bearing dinoflagellates } \\
\hline Citharistes regius Stein $1883^{\mathrm{a}}$ & $0.1-0.6$ & $20.7-30.1$ \\
\hline Histioneis biremis Stein $1883^{\mathrm{b}}$ & 0.1 & 30.1 \\
\hline H. carinata Kofoid 1907 & 0.1 & $29.1-29.5$ \\
\hline H. depressa Schiller 1933 & $0.1-0.7$ & $17.7-30.1$ \\
\hline H. dolon Murray \& Whitting 1899 & 0.1 & 29.1 \\
\hline H. elongata Kofoid \& Michener 1911 & $0.1-0.3$ & $17.5-30.1$ \\
\hline H. hippoperoides Kofoid \& Michener 1911 & $0.1-0.4$ & $16.5-30.1$ \\
\hline H. hyalina Kofoid \& Michener 1911 & 0.1 & $16.5-28.9$ \\
\hline H. inclinata Kofoid \& Michener 1911 & $0.1-0.2$ & $16.5-30.1$ \\
\hline H. joergensenii Schiller $1928^{\mathrm{a}}$ & 0.1 & $20.7-25.9$ \\
\hline H. longicollis Kofoid 1907 & 20.1 & $0.7-30.10$ \\
\hline H. mitchellana Murray \& Whitting 1899 & $0.1-0.2$ & $17.5-30.1$ \\
\hline H. oxypteris Schiller $1928^{\mathrm{a}}$ & $0.1-0.3$ & $20.7-30.1$ \\
\hline H. pacifica Kofoid \& Skogsberg $1928^{\mathrm{b}}$ & $0.1-0.2$ & $16.5-29.5$ \\
\hline H. panaria Kofoid \& Skogsberg 1928 & 0.1 & $25.9-30.1$ \\
\hline H. panda Kofoid \& Michener 1911 & 0.1 & 29.1 \\
\hline H. paulseni Kofoid 1907 & 0.1 & 20.7 \\
\hline H. reginella Kofoid \& Michener $1911^{\text {b }}$ & 0.1 & 30.1 \\
\hline H. reticulata Kofoid 1907 & 0.1 & $16.5-29.4$ \\
\hline H. rotundata Kofoid \& Michener 1911 & 0.3 & $29.1-30.1$ \\
\hline H. schilleri Böhm 1931 & 0.2 & 29.4 \\
\hline H. striata Kofoid \& Michener $1911^{\text {b }}$ & $0.1-0.6$ & $16.5-30.1$ \\
\hline H. tubifera Böhm 1931 & 0.1 & 29.1 \\
\hline H. vouki Schiller 1928 & 0.1 & 28.9 \\
\hline Ornithocercus carpentariae Wood $1963^{\mathrm{a}}$ & $0.1-0.2$ & $20.7-30.1$ \\
\hline O. heteroporus Kofoid 1907 & $0.1-2.0$ & $16.5-30.1$ \\
\hline O. magnificus Stein 1883 & $0.1-0.6$ & $16.5-30.1$ \\
\hline O. quadratus Schütt 1900 & $0.1-0.5$ & $16.5-30.1$ \\
\hline O. splendidus Schütt 1895 & 0.1 & 30.1 \\
\hline O. steinii Schütt 1900 & $0.1-0.2$ & $20.7-29.1$ \\
\hline O. thumii Schmidt 1888 & $0.1-0.4$ & $20.7-30.1$ \\
\hline Parahistioneis para Murray \& Whitting 1899 & 0.1 & $28.9-29.5$ \\
\hline P. paraformis Kofoid \& Skogsberg 1928 & $0.1-0.3$ & $25.9-29.5$ \\
\hline \multicolumn{3}{|l|}{ Endosymbiont-bearing dinoflagellates } \\
\hline Amphisolenia bidentata Schröder 1900 & $0.1-0.8$ & $25.9-30.1$ \\
\hline A. brevicauda Kofoid 1907 & 0.1 & $28.9-29.5$ \\
\hline A. elongata Kofoid $1907^{\mathrm{b}}$ & 0.1 & 29.5 \\
\hline A. globifera Stein 1883 & $0.1-1.2$ & $13.7-30.1$ \\
\hline A. inflata Murray \& Whitting $1899^{b}$ & 0.1 & $25.9-30.1$ \\
\hline A. laticincta Kofoid 1907 & 0.1 & 29.4 \\
\hline A. palmata Stein 1883 & $0.1-0.2$ & $28.9-29.5$ \\
\hline A. rectangulata Kofoid 1907 & 0.1 & $29.1-29.5$ \\
\hline A. schauinslandi Lemmermann 1899 & 0.1 & 28.9 \\
\hline A. thrinax Schütt 1893 & 0.1 & 29.4 \\
\hline Triposolenia bicornis Kofoid 1906 & $0.3-0.5$ & $25.9-28.9$ \\
\hline T. truncata Kofoid $1906^{\mathrm{b}}$ & 0.1 & 29.1 \\
\hline
\end{tabular}

gata Kofoid 1907, A. laticincta Kofoid 1907, A. schauinslandi Lemmermann 1899, A. thrinax Schütt 1893 and Triposolenia truncata Kofoid 1906 were each only encountered once at a single station.

The number of symbiont-bearing dinoflagellate species was quite low ( $\leq 4$ species) at Stns IN1 to IN3 (closest to South Africa). The number of species increased along the Indian Ocean transect and the highest numbers of species were found at Stns IN6 and IN7 (15 to 16 species; Fig. 3A). On the Broome transect, the lowest numbers of symbiontbearing dinoflagellate species (3 to 5 species) were found at the coastal stations (Stns BR1 to BR3), while up to 23 species of symbiont-bearing dinoflagellates were found at Stn BR9 (Fig. 3C).

\section{Horizontal and vertical distributions}

Ectosymbiont-bearing dinoflagellates

The abundances of ectosymbiontbearing dinoflagellates ranged from the detection limit of 0.1 to 1.5 cells $\mathrm{l}^{-1}$ on the Indian Ocean transect (Fig. 4A). The highest cell concentrations were found in the upper $100 \mathrm{~m}$, but cells were in some cases still present at 200 to $400 \mathrm{~m}$ depths. Depth-integrated abundances (0 to $400 \mathrm{~m}$ ) were in the range of 0 to $1.6 \times 10^{5}$ cells $\mathrm{m}^{-2}$, clearly showing the lowest cell densities at Stns IN1 to IN3 and the highest at Stns IN6 and IN7 (Fig. 3B).

Cell densities of ectosymbiont-bearing dinoflagellates on the Broome transect were in the range 0.1 to 4.0 cells $\mathrm{I}^{-1}$ (Fig. 4C). The coastal stations (Stns BR1 to BR4) had the lowest cell densities, while considerably higher densities were found near the shelf (Stns BR5 and BR6). The highest cell densities were found in the upper $100 \mathrm{~m}$, but cells were also present at $400 \mathrm{~m}$ depth. The integrated den-

reginella Kofoid \& Michener 1911, H. tubifera Böhm 1931, H. schilleri Böhm 1931, H. vouki Schiller 1928 and O. splendidus Schütt 1895.

The most common endosymbiont-bearing dinoflagellate species were Amphisolenia bidentata Schröder 1900 and A. globifera Stein 1883, both observed at 9 stations, while A. brevicaudata Kofoid 1907, A. elonsities were in the range of $4.6 \times 10^{3}$ to $4.5 \times 10^{5}$ cells m$^{-2}$

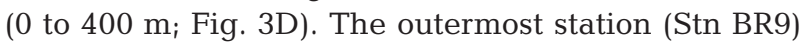
had the highest density per area, while the innermost station had the lowest.

Physical and chemical parameters, i.e. irradiance, temperature and inorganic nutrients, changed considerably along the transects, which may have influenced 

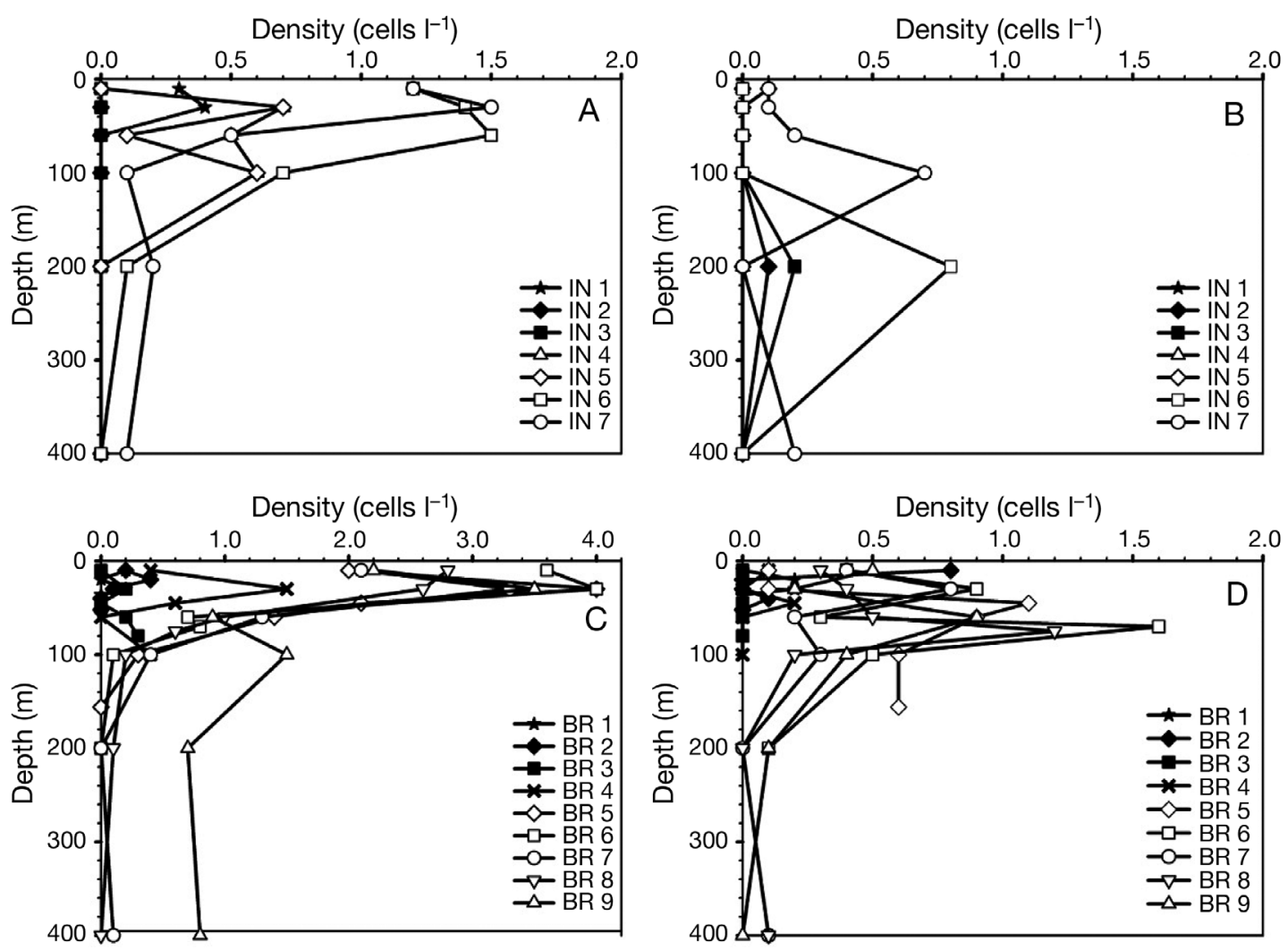

Fig. 4. Vertical distribution of $(A, C)$ ectosymbiont-bearing dinoflagellates and $(B, D)$ endosymbiont-bearing dinoflagellates in the $(A, B)$ Indian Ocean and $(C, D)$ Broome transects. Note the different scale in $(C)$

the distribution of the organisms. The highest cell densities were found in the euphotic zone, but cells were also found in the aphotic zone, where they received very low irradiances (Fig. 5A). Likewise, the highest cell densities were found at water temperatures $>20^{\circ} \mathrm{C}$, and cell concentrations clearly increased with temperature (Fig. 5B, Table 3), though some cells were still present at temperatures of 16 to $20^{\circ} \mathrm{C}$, and a few cells were even found at temperatures $<16^{\circ} \mathrm{C}$. In accordance with these observations, correlation analyses revealed that cell densities of ectosymbiont-bearing dinoflagellates were positively correlated to irradiance and temperature (Table 3).

In the euphotic zone, nearly all ectosymbiont-bearing dinoflagellates were found at inorganic nitrogen concentrations of $<2 \mu \mathrm{mol} \mathrm{l}^{-1}$ (Fig. 5C) and the highest cell densities ( 3.0 to 4.0 cells l$^{-1}$ ) were recorded at inorganic nitrogen concentrations $<0.5 \mu \mathrm{mol} \mathrm{l}^{-1}$. Despite this, no significant correlation was found between inorganic nitrogen concentration and cell density in the euphotic zone. Taking only data from the euphotic zone with temperatures $>16^{\circ} \mathrm{C}$ into consideration, the correlation between cell density and inorganic nitrogen was still not statistically significant. In the aphotic zone, the inorganic nitrogen concentration varied much more and reached concentrations as high as
$28 \mu \mathrm{mol} \mathrm{l^{-1 }}$; yet the correlation between cell densities and the concentration of inorganic nitrogen was not significant (Fig. 5D, Table 3).

In the euphotic zone, the vast majority of ectosymbiont-bearing dinoflagellates were found at $\mathrm{PO}_{4}{ }^{3-}$ concentrations $<0.50 \mathrm{mmol} \mathrm{l}^{-1}$ (Fig. $5 \mathrm{E}$ ), and the highest cell densities were found at stations which also had very low $\mathrm{PO}_{4}{ }^{3-}$ concentrations $\left(<0.10 \mu \mathrm{mol} \mathrm{l}{ }^{-1}\right.$; Fig. 5E). In accordance with this, a significant negative correlation between cell densities and inorganic phosphorous was observed in the euphotic zone (Table 3). In the aphotic zone, the concentrations of $\mathrm{PO}_{4}{ }^{3-}$ varied more and concentrations as high as $2 \mu \mathrm{mol} \mathrm{l}^{-1}$ were found (Fig. 5F). However, the correlation between cell density and $\mathrm{PO}_{4}{ }^{3-}$ concentration in the aphotic zone was not significant (Fig. 5F, Table 3).

\section{Endosymbiont-bearing dinoflagellates}

Abundances of endosymbiont-bearing dinoflagellates were very low along the Indian Ocean transect and in some cases (Stns IN1, IN4 and IN5), even absent (Figs. 3B \& 4B). The abundance ranged from the detection limit of 0.1 to 0.8 cells $^{-1}$. Highest concentrations were generally found between 100 and $200 \mathrm{~m}$ depth, 

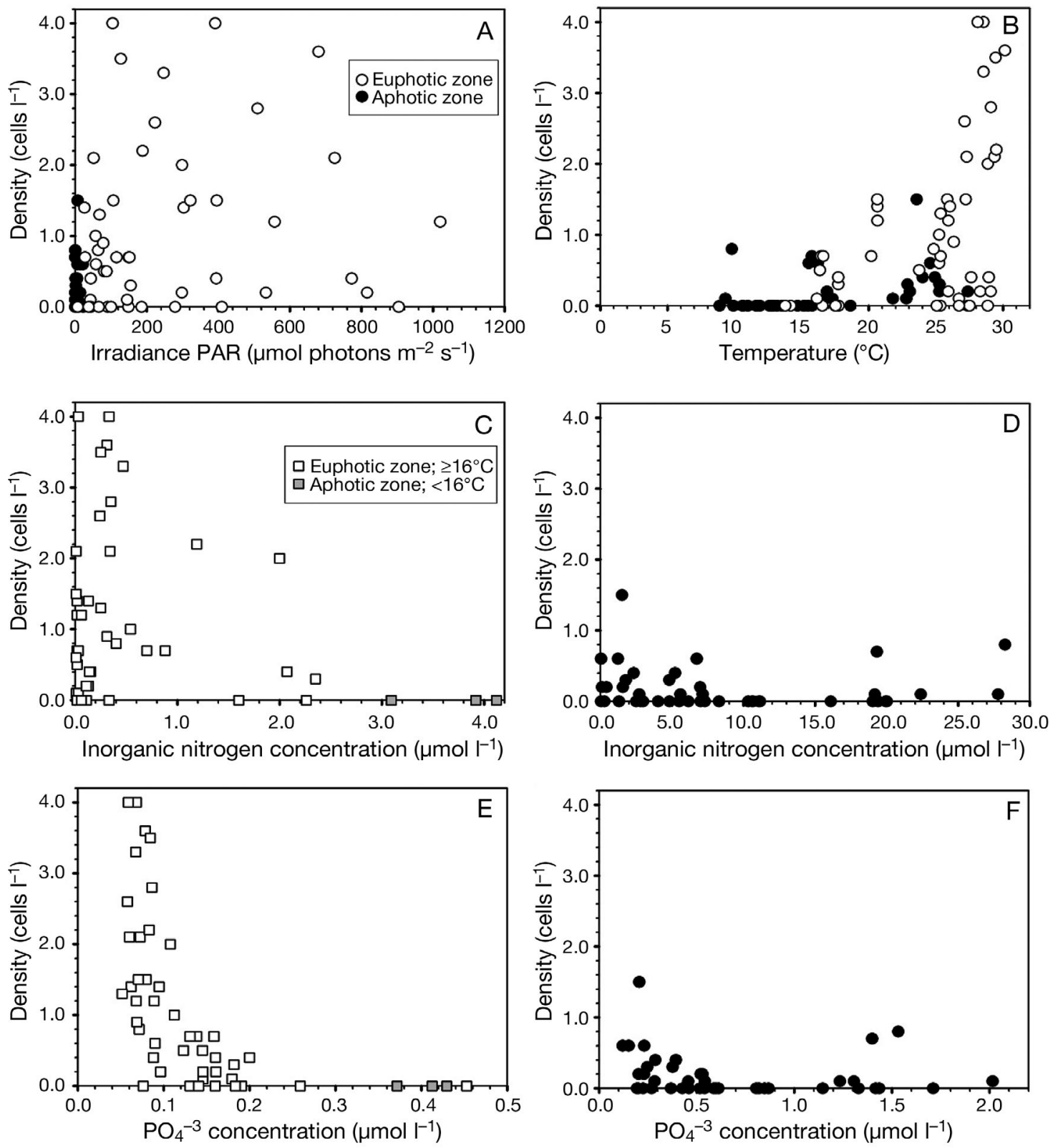

Fig. 5. Ectosymbiont-bearing dinoflagellates. Relationship between cell density and (A) irradiance; (B) temperature; inorganic nitrogen concentration in the (C) euphotic zone and (D) aphotic zone; and $\mathrm{PO}_{4}{ }^{3-}$ concentration in the (E) euphotic zone and (F) aphotic zone. $\mathrm{PAR}=$ photosynthetically active radiation

Table 3. Pearson's correlation coefficient (r) between density of symbiont-bearing dinoflagellates and selected physical and chemical variables. Significance evaluated at $95 \%$ confidence level $(\mathrm{p} \leq 0.05) .{ }^{* *} \mathrm{p}<0.01$. ns: not significant; $\mathrm{n}$ : number of data points

\begin{tabular}{|c|c|c|c|c|c|c|c|}
\hline \multirow[t]{2}{*}{ Variable } & \multicolumn{4}{|c|}{ Density of ectosymbiont-bearing dinoflagellates } & \multicolumn{3}{|c|}{ Density of endosymbiont-bearing dinoflagellates } \\
\hline & $\begin{array}{l}\text { All data } \\
\mathrm{r}(\mathrm{n}=92)\end{array}$ & $\begin{array}{l}\text { Euphotic zone } \\
\mathrm{r}(\mathrm{n}=49)\end{array}$ & $\begin{array}{c}\text { Euphotic zone }{ }^{\mathrm{a}} \\
\text { r }(\mathrm{n}=46)\end{array}$ & $\begin{array}{l}\text { Aphotic zone } \\
\text { r }(\mathrm{n}=43)\end{array}$ & $\begin{array}{l}\text { All data } \\
\mathrm{r}(\mathrm{n}=92)\end{array}$ & $\begin{array}{l}\text { Euphotic zone } \\
\mathrm{r}(\mathrm{n}=49)\end{array}$ & $\begin{array}{l}\text { Aphotic zone } \\
\text { r }(\mathrm{n}=43)\end{array}$ \\
\hline Temperature & $0.548^{* *}$ & & & & $0.407^{* *}$ & & \\
\hline Irradiance & $0.539^{* *}$ & & & & $0.158(\mathrm{~ns})$ & & \\
\hline Inorganic nitrogen & & $-0.224(\mathrm{~ns})$ & $-0.031(\mathrm{~ns})$ & -0.238 (ns) & & $-0.127(\mathrm{~ns})$ & $-0.108(\mathrm{~ns})$ \\
\hline $\mathrm{PO}_{4}^{3-}$ & & $-0.649^{* *}$ & $-0.647^{* *}$ & -0.199 (ns) & & $-0.437^{* *}$ & -0.153 (ns) \\
\hline
\end{tabular}


indicating a subsurface maximum, but cells were recorded down to $400 \mathrm{~m}$ (Fig. 4B). Depth integrated ( 0 to $400 \mathrm{~m}$ ) cell densities were between $1.5 \times 10^{4}$ and $1.2 \times 10^{5}$ cells $\mathrm{m}^{-2}$, with the highest values found at Stns IN6 and IN7 (Fig. 3B).

Cell concentrations of endosymbiont-bearing dinoflagellates ranged from 0 to 1.6 cells $~^{-1}$ along the Broome transect (Fig. 4D). Very low abundances were found at Stns BR1, BR3 and BR4 (<0.2 cells $\left.{ }^{-1}\right)$, while the highest cell concentrations were found at Stn BR6 (at $70 \mathrm{~m}$;
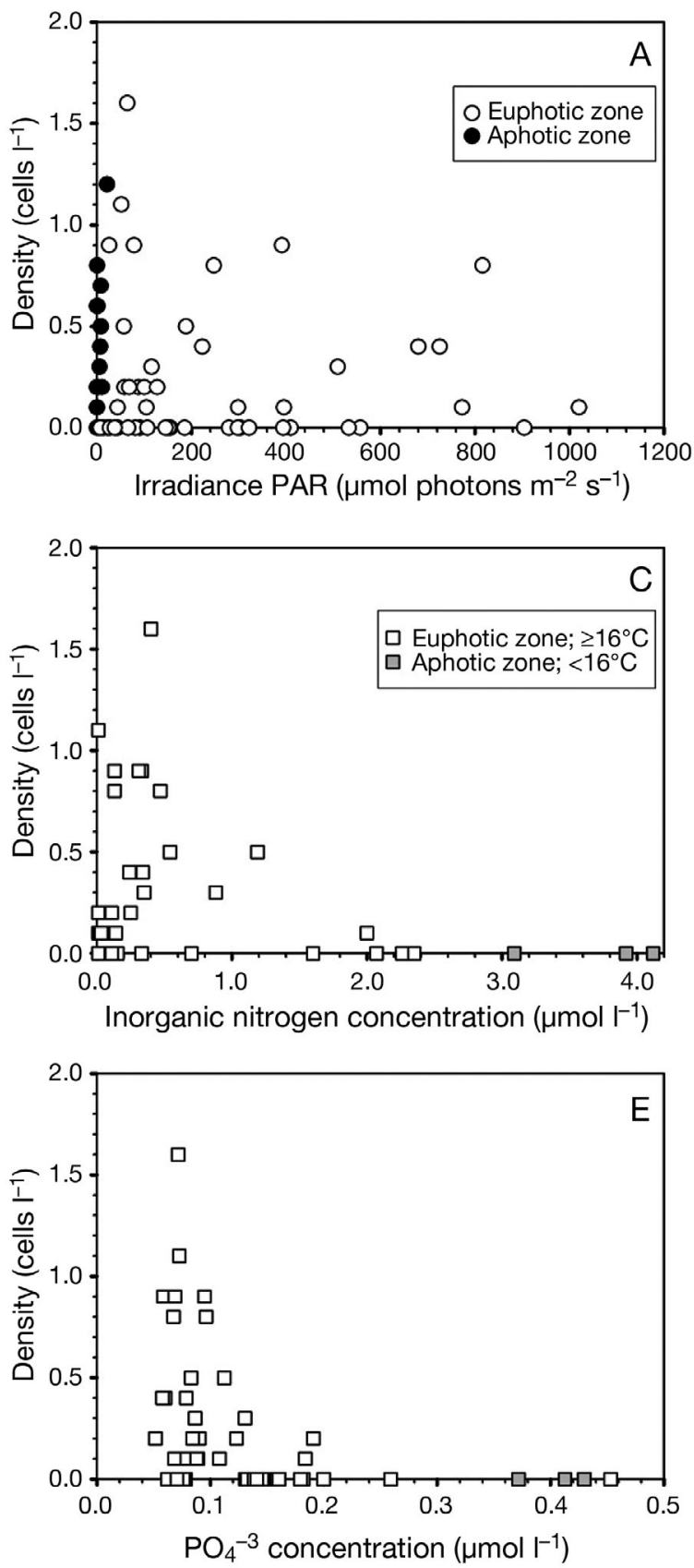

Fig. 4D). The highest cells densities were always found in the upper $100 \mathrm{~m}$ depth of the water column. However, some cells still occurred in deeper water (Fig. 4D). The density per unit area ranged from below the detection limit to $1.77 \times 10^{5}$ cells $\mathrm{m}^{-2}$, with lowest concentrations at Stns BR1 to BR4 and highest at Stns BR5 (Fig. 3D).

Taking all the data into consideration, endosymbiont-bearing dinoflagellate abundances were not significantly correlated to irradiance (Table 3, Fig. 6A). Abundances were highest at temperatures $>22^{\circ} \mathrm{C}$ and
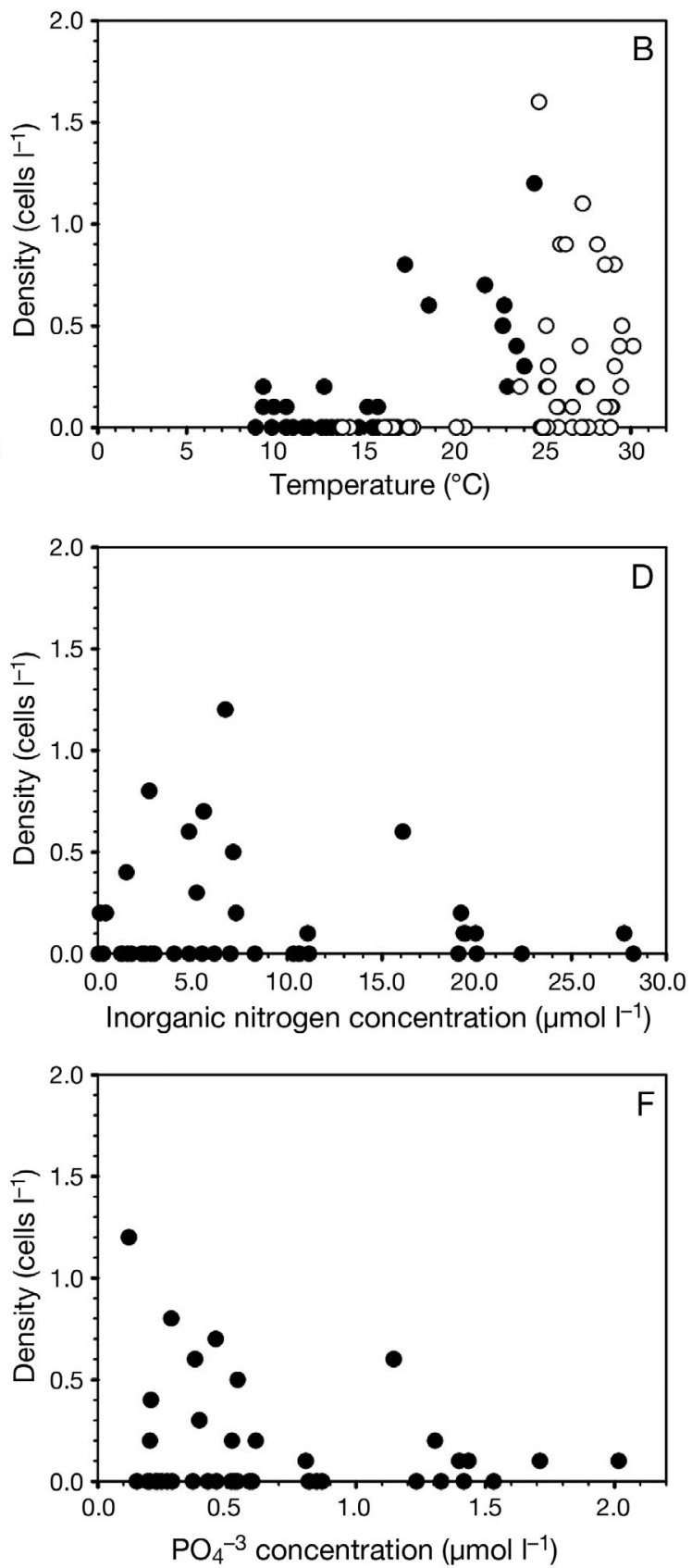

Fig. 6. Endosymbiont-bearing dinoflagellates. Relationship between cell density and (A) irradiance; (B) temperature; inorganic nitrogen concentration in the (C) euphotic zone and (D) aphotic zone; and $\mathrm{PO}_{4}{ }^{3-}$ concentration in the (E) euphotic zone and (F) aphotic zone. $\mathrm{PAR}=$ photosynthetically active radiation 
cell concentrations decreased as a function of temperature down to $10^{\circ} \mathrm{C}$ (Pearson's correlation coefficients, $\mathrm{p}<0.01$; Table 3, Fig. 6B). Some cells were, however, still present at temperatures $<10^{\circ} \mathrm{C}$. Nevertheless, a significant correlation was found between temperature and cell density (Table 3, Fig. 6B).

The highest cell concentrations of endosymbiont-bearing dinoflagellates in the euphotic zone were found when inorganic nitrogen concentrations were low $\left(<1 \mu \mathrm{mol} \mathrm{l}^{-1}\right.$; Fig. 6C). Yet, the correlation between cell density and the concentration of inorganic nitrogen was not significant (Table 3). In the aphotic zone, the concentrations of inorganic nitrogen were considerably higher than in the euphotic zone (Fig. 6D). However, no correlation between cell concentration and inorganic nitrogen was found.
The endosymbiont-bearing dinoflagellates were most abundant in the euphotic zone at low $\mathrm{PO}_{4}{ }^{3-}$ concentrations (Fig. 6E), and a negative correlation between cell densities and $\mathrm{PO}_{4}{ }^{3-}$ concentrations was found ( $\mathrm{p}<0.01$; Table 3 ). Such a negative correlation was not found in the aphotic zone (Fig. 6F, Table 3).

\section{Light microscopy}

All Ornithocercus spp. and Histioneis spp. cells examined contained extracellular cyanobacterial ectosymbionts, which were located within the cingulum (Fig. 7A-E). Many Ornithocercus spp. cells also had large rod-shaped non-photosynthetic bacteria on their
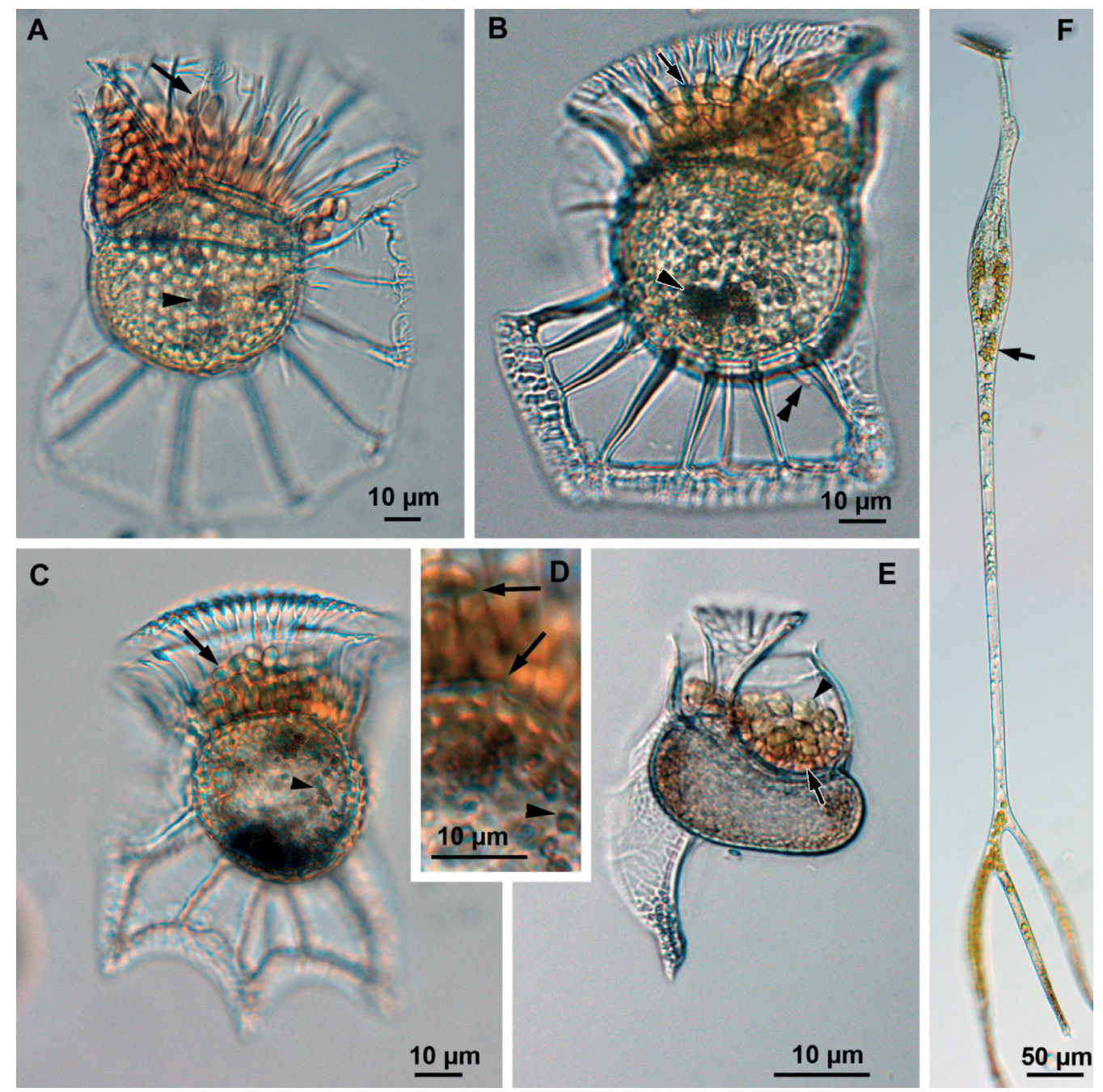

Fig. 7. Light microscopy of live cells. (A) Ornithocercus steinii with numerous cyanobacterial ectosymbionts present in the cingulum (arrow). Food vacuoles (arrowhead). (B) O. quadratus: cyanobacterial ectosymbionts (arrow), food vacuole (arrowhead), large bacteria (double arrowhead). (C) O. magnificus: cyanobacterial ectosymbionts (arrow); note the small putative food vacuoles with the same colour as the cyanobacterial ectosymbionts (arrowhead). (D) Detail of the same cell as in (C), with arrows showing the length of a cyanobacterial ectosymbiont. (E) Histioneis carinata: 2 different types of cyanobacterial ectosymbionts are present (arrowhead and arrow). (F) Amphisolenia thrinax: yellowish endosymbionts (arrow) 
sulcal lists (Fig. 7B). Ectosymbiotic bacteria were not observed on cells of Histioneis spp. or Amphisolenia spp. Most cells of Ornithocercus spp. contained numerous food vacuoles of various sizes (Fig. 7A-D). In some cases they had a striking resemblance to the cyanobacterial ectosymbionts, having the same size and colour (Fig. 7A). In other cases inclusions were very small and in a state of degradation (Fig. $7 \mathrm{C}, \mathrm{D})$. In the genus $\mathrm{Am}$ phisolenia, only endosymbionts were found (Fig. 7F).

\section{TEM}

Cells of Ornithocercus magnificus and O. quadratus were examined using TEM. All cells had the typical dinoflagellate organelles including a nucleus with condensed chromosomes (dinokaryon) situated in the posterior part of the cell (Fig. 8A). In both species, cyanobacterial ectosymbionts were present in the cingulum

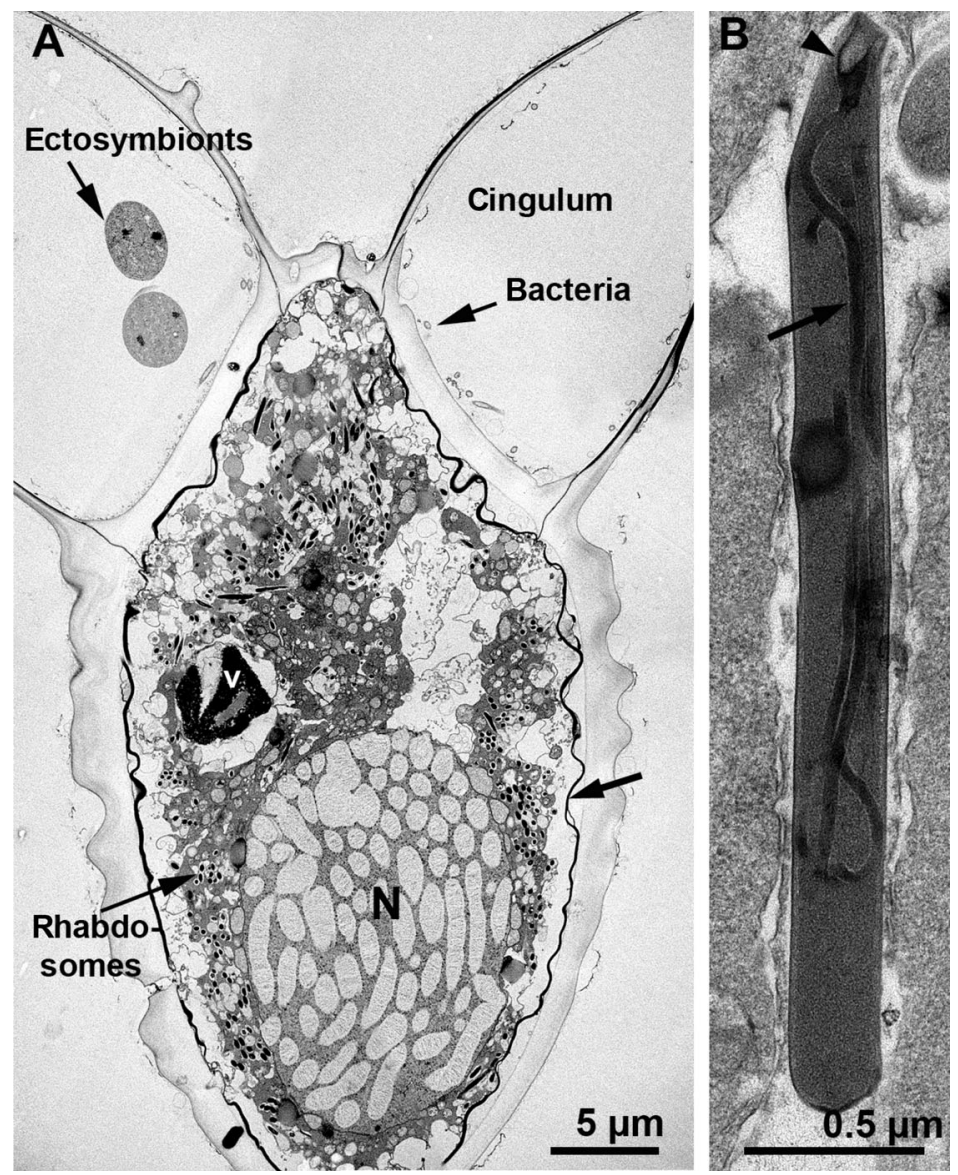

Fig. 8. Transmission electron microscopy of Ornithocercus magnificus. (A) Longitudinal section of a cell. Two cyanobacterial ectosymbionts and small bacteria are present in the cingulum. Numerous rhabdosomes are present within the cell. A dense membrane layer subtends the thecal plates (arrow). Nucleus (N), food vacuole (V). (B) Longitudinal section of a rhabdosome. The inner coiled tube (arrow) terminates in a funnel-like structure (arrowhead)
(Fig. 8A), though a substantial number were lost during the fixation process. The cingulum also contained small rod-shaped heterotrophic bacteria (Fig. 8A).

An electron-dense layer, about $0.20 \mu \mathrm{m}$ in thickness, subtended the thecal plates just below the inner plate membrane (Fig. 8A). It appeared to be a more or less continuous layer around the cell, though at some places it was interrupted and less dense. Here it became evident that the layer consisted of stacked membranes. An extensive number of rod-shaped bodies, so-called rhabdosomes, were scattered throughout the cytoplasm (Fig. 8A). They measured about $3 \mu \mathrm{m}$ in length and $0.25 \mu \mathrm{m}$ in width. Inside the rod or cylinder was a coiled electron-dense tube situated in a less dense matrix (Fig. 8B). The tube seemed to be attached to the putative posterior part of the cylinder and terminated in a funnel-like structure at the slightly pointed 'anterior' end (Fig. 8B). The rhabdosomes were never seen associated with the cell surface or the thecal pores.

The Ornithocercus spp. cells contained a 'cytostome' surrounded by thin plates. A microtubular strand, similar to the peduncle microtubular strands observed in a number of other dinoflagellates, was located inside the cytostome (Fig. 9A). The cytostome was not studied in detail but appeared to be similar to that reported in Dinophysis spp. (Jacobson \& Andersen 1994).

All cells sectioned (7 Ornithocercus magnificus and 2 O. quadratus cells) contained food vacuoles. The contents of these were usually in such a state of degradation that the identity of prey items was impossible. Most food vacuoles contained numerous rod-shaped trichocystlike bodies with a diameter of about $500 \mathrm{~nm}$, which most likely came from an ingested ciliate (Fig. 9B,C,F). One food vacuole contained remnants of a chloroplast having an internal rod-shaped pyrenoid and parallel-running thylakoid bands (Fig. 9E). The chloroplast was located close to a trichocyst-like body (Fig. 9D).

\section{DISCUSSION}

The role of symbionts for the dinoflagellates

\section{Ectosymbionts}

In the present study, light-microscopic observations revealed striking similarities between some of the food vacuoles and the extracellular symbionts, the same colour, size and shape was evident. However, in TEM sections, the 
food vacuole contents were in such a state of degradation that we could not confirm this. Nevertheless, Lucas (1991) observed remnants inside a food vacuole resembling the extracellular symbionts in his TEM preparations, suggesting that the heterotrophic dinoflagellates may ingest the symbionts. In other words, it
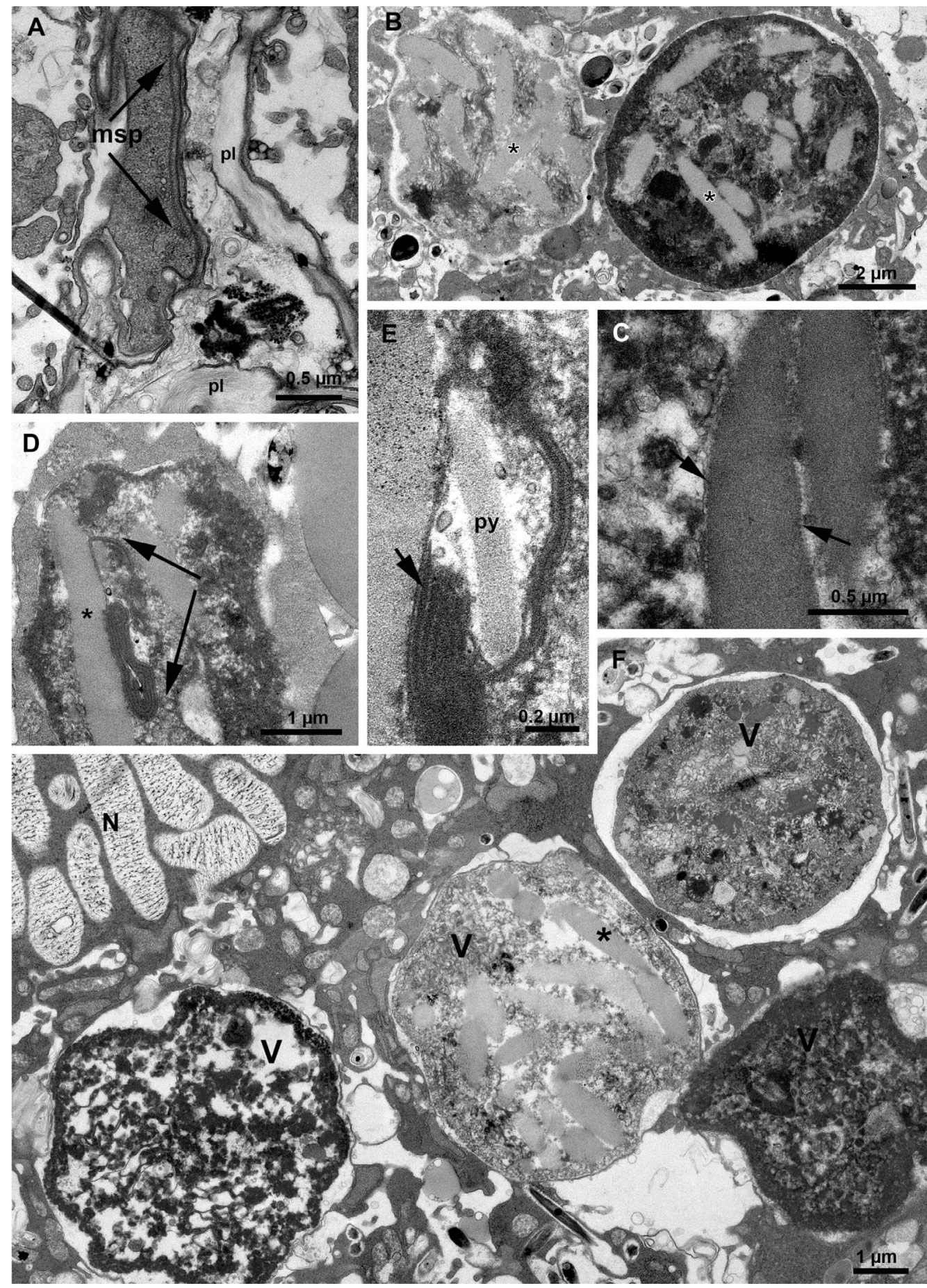

Fig. 9. Transmission electron microscopy of (A-E) Ornithocercus magnificus and (F) O. quadratus. (A) Inner part of the 'cytostome' delineated by thin thecal plates (pl). msp: microtubular strand of the peduncle. (B) Two 'typical' food vacuoles with numerous rod-shaped trichocyst-like structures (*; also in other panels). (C) Details of trichocyst-like structure within a food vacuole. Note the delicate substructure of the surface (arrows). (D) Food vacuole with remnants of a chloroplast (arrows). (E) Another section of the food vacuole in (D) revealing a pyrenoid (py) and thylakoids bands of the chloroplast (arrow). (F) Four different food vacuoles $(\mathrm{V})$ with various partly digested prey remnants. N: nucleus 
looks like the heterotrophic dinoflagellates are growing their own 'vegetables'.

However, the ectosymbiont-bearing dinoflagellates are probably not entirely dependent on cyanobacteria as a food source. It is well known that other members of the order Dinophysiales feed on ciliates by the use of a peduncle (e.g. Dinophysis spp. and Oxyphysis spp.; Elbrächter 1991, Hansen 1991, Park et al. 2006). In food vacuoles of Ornithocercus spp., we found trichocyst-like remnants that most likely originated from ciliates. The trichocyst-like structures we observed are of similar type to those found in food vacuoles of $O x y$ physis oxytoxoides (Jacobson \& Andersen 1994, their Figs. 44 \& 45).

We also found remnants of a chloroplast in one of the food vacuoles of Ornithocercus spp. The identity of this chloroplast is uncertain, but its pyrenoid bears some resemblance to the pyrenoids found in certain prymnesiophytes, e.g. Chrysochromulina apheles (Moestrup \& Thomsen 1986, their Fig. 8). Small prymnesiophytes did account for a substantial amount of the nanoplanktonic biomass in the samples taken (W. Tarangkoon et al. unpubl. obs.), but the close proximity of the chloroplast remnants to the trichocyst in the TEM section, and the scarcity of such degraded chloroplasts within food vacuoles in general in the Ornithocerus spp. cells indicated that algal cells were ingested by the ciliate before they entered Ornithocercus spp.

How the ectosymbiont-bearing dinoflagellates feed is unknown, but the presence of a cytostome with a microtubular strand similar to that found in Dinophysis spp. suggests that Ornithocercus spp. also uses a peduncle in food uptake (Hansen 1991, Jacobson \& Andersen 1994). Also, Taylor (cited by Lucas 1991) observed a veil-like structure extruded from the flagellar pore of Ornithocercus sp.

We also found rhabdosomes in Ornithocercus spp., which have only been described in detail in Dinophysis acuminata (Vesk \& Lucas 1986). Lucas \& Vesk (1990) found a few rhabdosomes close to the apical pore of $D$. acuminata but no obvious signs of emission have ever been observed. Rhabdosomes are believed to function as trichocysts and be involved in prey capture (Lucas \& Vesk 1990), but more research is required to understand their function.

\section{Endosymbionts}

Light-microscopic observations revealed numerous healthy endosymbionts inside Amphisolenia spp. Based on the present observations and what is known from the literature, these symbionts can either be eukaryotic or prokaryotic and thus may play different roles with regard to $\mathrm{N}_{2}$ fixation (Lucas 1991). There is no doubt that the symbionts perform photosynthesis, but to what extent the heterotrophic dinoflagellates actually ingest the symbionts is unknown. It is, however, interesting that Lucas (1991) found dividing symbionts inside A. globifera, suggesting that the symbionts multiply inside the heterotrophic dinoflagellate. To what extent these symbionts are permanently incorporated into the heterotrophic dinoflagellates is presently unknown.

\section{Spatial distribution of symbiont-bearing dinoflagellates}

Surface temperatures ranged from 12 to $30^{\circ} \mathrm{C}$ during the cruise. The highest cell concentrations and species diversity were found at temperatures $>20^{\circ} \mathrm{C}$ (Figs. 5B $\& 6 \mathrm{~B}$, Table 2). Dinoflagellates bearing either ecto- or endosymbionts in the photic zone were not observed at temperatures below 16 and $23^{\circ} \mathrm{C}$, respectively. We found symbiont-bearing dinoflagellates at lower tem-

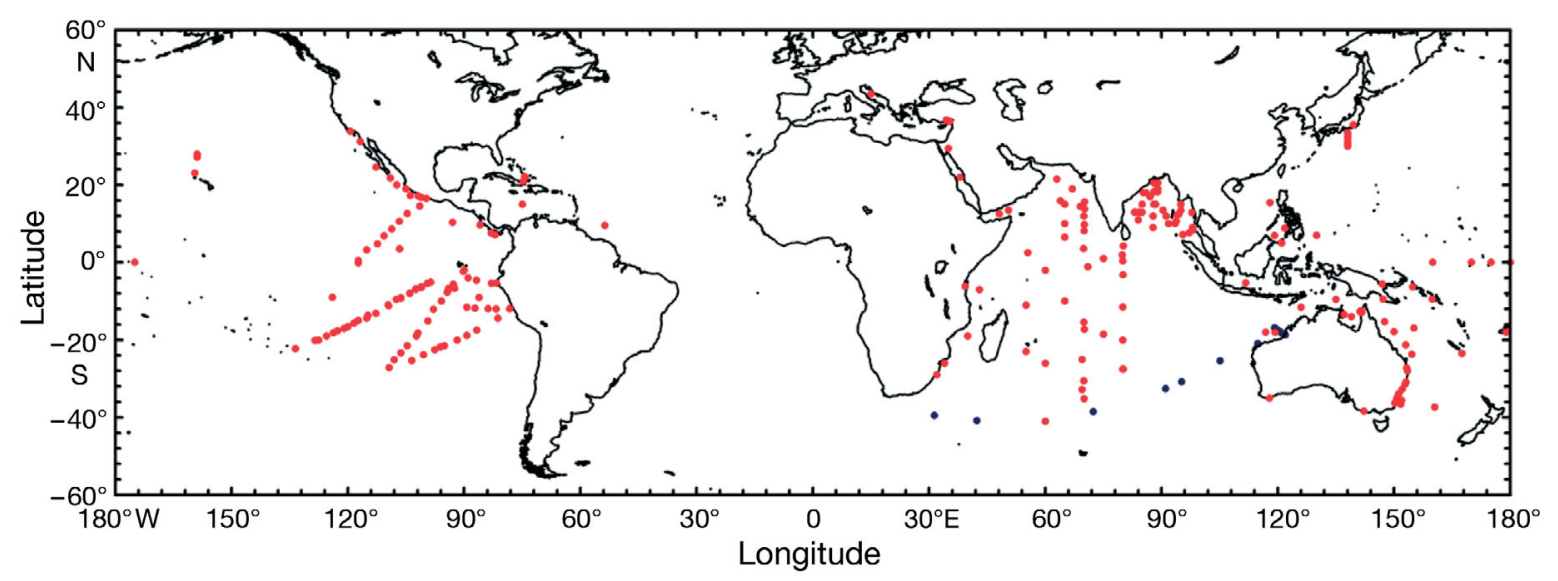

Fig. 10. Geographic distribution of dinoflagellates with symbionts. Data from references in Table 4 (red dots) and data from the present study (blue dots) 


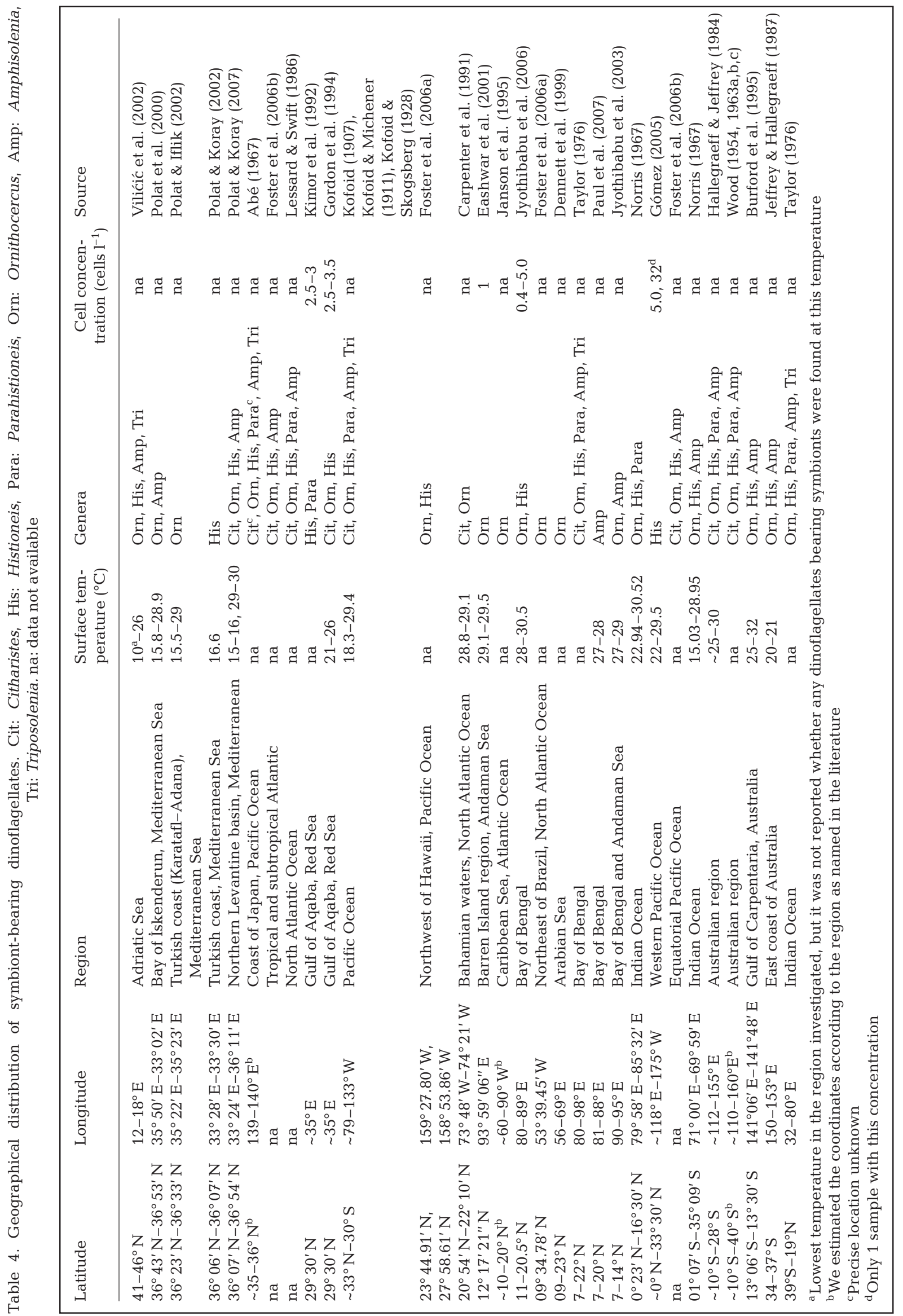


peratures, but this was always in the aphotic zone and it cannot be ruled out that these cells represent cells sinking from the euphotic zone.

A literature survey on the geographical distribution of symbiont-bearing dinoflagellates (i.e. the genera Amphisolenia, Citharistes, Histioneis, Ornithocercus, Parahistioneis and Triposolenia) in combination with the present data set suggest that their distribution is restricted to tropical, subtropical and warm-temperate seas from about $46^{\circ} \mathrm{N}$ to $40^{\circ} \mathrm{S}$ (summarised in Table 4, Fig. 10). Previous reports have focused on species diversity (not cell density) in an area with often very little information on temperature and exact location of samples containing symbiont-bearing dinoflagellates. Thus, reported surface temperatures are therefore often only given as ranges within geographical areas visited or as seasonal ranges. Nevertheless, symbiontbearing dinoflagellates have only been reported with certainty in waters which have a surface temperature in the range of roughly 15 to $30^{\circ} \mathrm{C}$ (Table 4 ). This is in accordance with our results.

The reasons for the apparent dependency on fairly high temperatures in these organisms are unknown, as none of them yet have been cultured in the laboratory. It may be a direct temperature effect on the heterotrophic dinoflagellate or its symbionts. However, a number of indirect factors may also lead to this apparent high temperature requirement, including a lack of seasonality in light and inorganic nitrogen concentration.

In the present study, symbiont-bearing dinoflagellates were mainly found in the euphotic zone, suggesting that they rely on light for photosynthesis of their symbionts. Cells were also found below the euphotic zone, as far down as $200 \mathrm{~m}$ and on some occasions $400 \mathrm{~m}$, but generally in much lower cell densities (Fig. 4). Similar vertical distributions of these dinoflagellates have been found previously in other parts of the world (Kofoid \& Skogsberg 1928, Gordon et al. 1994, Gómez 2005, Jyothibabu et al. 2006).

It is evident from our data set that the highest cell concentrations of symbiont-bearing dinoflagellates were found in warm waters characterised by very low nutrient and chl a concentrations (Figs. 3B,D, 5 \& 6, Table 3). However, it is important to note that these dinoflagellates were not very abundant in the Broome coastal waters with water depths below 150 to $200 \mathrm{~m}$, even though inorganic nitrogen and phosphorous concentrations were very low (Figs. 2 \& 3). So, although nutrient concentration and temperature are important factors determining the distribution of these organisms, other factors must play an important role as well.

In coastal waters, transport of nutrients from land or from mixing of the water column will increase primary production compared to offshore waters, allowing increased zooplankton biomass and thereby increased turnover rate of production. A. W. Visser et al. (unpubl.) documented considerable water mixing at the first 3 stations along the Indian Ocean transect transporting nutrients from the pycnocline to the surface waters, leading to increased primary productions at these stations. Also, data published from the Indian Ocean transect (same cruise) show that the copepod biomass at the coastal stations on the Indian Ocean transect was 4 -fold that of the more oceanic stations (Jaspers et al. 2009). Thus, turnover rates in the planktonic food web are definitely higher in the coastal waters of the Indian Ocean transect. Symbiont-bearing dinoflagellates are in general quite large cells and most likely have fairly low maximum growth rates (Hansen et al. 1997) Thus, in coastal waters where turnover rates of organic matter are high, these dinoflagellates will probably not be able to outgrow the losses due to grazing.

\section{CONCLUSIONS}

High abundances and species diversity of symbiontbearing dinoflagellates were found in the photic zone in warm offshore waters characterised by low nutrient and chl a concentrations. We found indications that ectosymbiont-bearing dinoflagellates not only seem to ingest their ectosymbionts, but also ingest other prey items such as ciliates. Thus, it seems that these dinoflagellates cope with low-nutrient environments by using a multi-resource strategy. To what extent this also applies to endosymbiont-bearing dinoflagellates is unknown at present. Rates of growth, photosynthesis and $\mathrm{N}_{2}$ fixation as well as grazing loss rates of symbiont-bearing dinoflagellates are still lacking in the literature. More research is needed to unravel their functional biology and understand their role in the pelagic food web.

Acknowledgements. The Danish Galathea expedition and the captain of HMDS 'Vædderen', C. Smidt, and his crew are thanked for excellent assistance in sampling. We thank B. Søeborg for technical assistance and T. G. Nielsen for providing the nutrient data and for valuable comments and suggestions to the manuscript. The project was supported by grants from Danish Natural Sciences Research Council (FNU grant nos. 272-05-0333 and 272-06-0485 to P.J.H. and grant no. $277-$ 05-0421 to G.H.), the Danish Expedition foundation, the Carlsberg Foundation and the Knud Højgaards Fond. The present work was carried out as part of the Galathea 3 expedition under the auspices of the Danish Expedition Foundation. This is Galathea 3 contribution no. P27.

\section{LITERATURE CITED}

Abé TH (1967) The armoured Dinoflagellata: II. Prorocentridae and Dinophysidae (C)-Ornithocercus, Histioneis, Amphisolenia and others. Publ Seto Mar Biol Lab 15: 79-116 
Andersen P, Kristensen HS (1995) Rapid and precise identification and counting of the cate dinoflagellates using epifluorescense microscopy. In: Lassus P, Arzul G, Erard E, Gentien P, Marcaillou C (eds) Harmful marine algal blooms. Lavoisier, Paris, p 713-718

Burford M, Rothlisberg PC, Wang YC (1995) Spatial and temporal distribution of tropical phytoplankton species and biomass in the Gulf of Carpentaria, Australia. Mar Ecol Prog Ser 118:255-266

Carpenter EJ, Chang J, Shapiro LP (1991) Green and blue fluorescing dinoflagellates in Bahamian waters. Mar Biol 108:145-149

Dennett MR, Caron DA, Murzov SA, Polikarpov IG, Gavrilova NA, Georgieva LV, Kuzmenko LV (1999) Abundance and biomass of nano- and microplankton during the 1995 northeast monsoon and spring intermonsoon in the Arabian Sea. Deep-Sea Res II 46:1691-1717

Eashwar M, Kuberaraj K, Nallathambi T, Govindarajan G (2001) A note on the plankton from Barren Island region, Andamans. Curr Sci 81:651-654

Elbrächter M (1991) Food uptake mechanisms in phagotrophic dinoflagellates and classification. In: Patterson DJ, Larsen J (eds) The biology of free-living heterotrophic flagellates. Systematics Assocation, Spec Vol 45. Clarendon Press, Oxford, p 303-312

Farnelid H, Riemann L (2008) Heterotrophic $\mathrm{N}_{2}$-fixing bacteria: overlooked in the marine nitrogen cycle? In: Couto GN (ed) Nitrogen fixation research progress. Nova Science Publishers, New York, p 409-423

Field CB, Behrenfeld M, Randerson JT, Falkowski P (1998) Primary production of the biosphere: integrating terrestrial and oceanic components. Science 281:237-240

Foster RA, Carpenter EJ, Bergman B (2006a) Unicellular cyanobacterial ectosymbionts in open ocean dinoflagellates, radiolarians, and tintinnids: ultrastructural characterization and immuno-localization of phycoerythrin and nitrogenase. J Phycol 42:453-463

Foster RA, Collier JL, Carpenter EJ (2006b) Reverse transcription PCR amplification of cyanobacterial symbiont $16 \mathrm{~S}$ rRNA sequences from single non-photosynthetic eukaryotic marine planktonic host cells. J Phycol 42:243-250

Gómez F (2005) Histioneis (Dinophysiales, Dinophyceae) from the western Pacific Ocean. Bot Mar 48:421-425

Gordon N, Angel DL, Neori A, Kress N, Kimor B (1994) Heterotrophic dinoflagellates with symbiotic cyanobacteria and nitrogen limitation in the Gulf of Aqaba. Mar Ecol Prog Ser 107:83-88

Grasshoff K (ed) (1976) Methods of seawater analysis, 2nd edn. Verlag Chemie, Weinheim

Hallegraeff GM, Jeffrey SW (1984) Tropical phytoplankton species and pigments of continental shelf waters of North and North-West Australia. Mar Ecol Prog Ser 20:59-74

Hansen PJ (1991) Dinophysis - a planktonic dinoflagellate genus which can act both as a prey and a predator of a ciliate. Mar Ecol Prog Ser 69:201-204

Hansen PJ, Hansen B, Bjørnsen PK (1997) Zooplankton grazing and growth: scaling within the size range $2 \mu \mathrm{m}$ to $2000 \mu \mathrm{m}$. Limnol Oceanogr 42:687-704

Jacobson DM, Andersen RA (1994) The discovery of mixotrophy in photosynthetic species of Dinophysis (Dinophyceae): light and electron microscopical observations of food vacuoles in Dinophysis acuminata, D. norvegica and two heterotrophic dinophysoid dinoflagellates. Phycologia 33:97-110

Janson S, Carpenter EJ, Bergman B (1995) Immunolabelling of phycoerythrin, ribulose 1,5-bisphosphate carboxylase/ oxygenase and nitrogenase in the unicellular cyanobiont of Ornithocercus spp. (Dinophyceae). Phycologia 34:171-176 Jaspers C, Nielsen TG, Carstensen J, Hopcroft RR, Møller EF (2009) Metazooplankton distribution across the southern Indian Ocean with emphasis on the role of Larvaceans. J Plankton Res 31:525-540

Jeffrey SW, Hallegraeff GM (1987) Phytoplankton pigments, species and light climate in a complex warm core eddy of the East Australian Current. Deep-Sea Res A 34:649-673

Jespersen AM, Christoffersen K (1987) Measurements of chlorophyll-a from phytoplankton using ethanol as extraction solvent. Arch Hydrobiol 109:445-454

Jyothibabu R, Madhu NV, Maheswara PA, Nair KKC, Venugopal P, Balasbramanian T (2003) Dominance of dinoflagellates in microzooplankton community in the oceanic regions of the Bay of Bengal and the Andaman Sea. Curr Sci 84:1247-1253

Jyothibabu R, Madhu NV, Maheswara PA, Asha-Devi CR, Balasbramanian T, Nair KKC, Achuthankutty CT (2006) Environmentally-related seasonal variation in symbiotic associations of heterotrophic dinoflagellates with cyano bacteria in the western Bay of Bengal. Symbiosis 42:51-58

Kimor B, Gordon N, Neori A (1992) Symbiotic associations among the microplankton in oligotrophic marine environments, with special reference to the Gulf of Aqaba, Red Sea. J Plankton Res 14:1217-1231

Kofoid CA (1906) Dinoflagellata of the San Diego region. II. On Triposolenia, a new genus of the Dinophysidae. Univ Calif Publ Zool 3(6):93-116

Kofoid CA (1907) New species of dinoflagellates. Bull Mus Comp Zool Harvard Coll L(6):161-208

Kofoid CA, Michener JR (1911) New species of dinoflagellates. Bull Mus Comp Zool Harvard Coll LIV:265-302

Kofoid CA, Skogsberg T (1928) The dinoflagellata: the dinophysoidae. Mem Mus Comp Zool Harvard 51:1-766

Lessard E, Swift E (1986) Dinoflagellates from the North Atlantic classified as phototrophic or heterotrophic by epifluorescence microscopy. J Plankton Res 8:1209-1215

Li WK (1995) Composition of ultraphytoplanktonin the central North Atlantic. Mar Ecol Prog Ser 122:1-8

Lucas IAN (1991) Symbionts of the tropical Dinophysiales (Dinophyceae). Ophelia 33:213-224

Lucas IAN, Vesk M (1990) The fine structure of two photosynthetic species of Dinophysis (Dinophysiales, Dinophyceae). J Phycol 26:345-357

> Maranon E, Behrenfeld MJ, Gozalez N, Mourino B, Zubkov MV (2003) High variability of primary production in oligotrophic waters of the Atlantic Ocean: uncoupling from phytoplankton biomass and size structure. Mar Ecol Prog Ser 257:1-11

Moestrup Ø, Thomsen HA (1986) Ultrastructure and reconstruction of the flagellar apparatus in Chrysochromulina apheles sp. nov. (Prymnesiophyceae = Haptophyceae). Can J Bot 64:593-610

Norris RE (1967) Algal consortisms in marine plankton. In: Krishnamurthy V (ed) Proc Sem Sea, Salt and Plants. Central Salt and Marine Chemicals Research Institute, Bhavnagar, p 178-189

Park MG, Kim S, Kim HS, Myung G, Kang YG, Yih W (2006) First successful culture of the marine dinoflagellate Dinophysis acuminata. Aquat Microb Ecol 45:101-106

Paul JT, Ramaiah N, Gauns M, Fernandes V (2007) Preponderance of a few diatom species among the highly diverse microphytoplankton assemblages in the Bay of Bengal. Mar Biol 152:63-75

Polat S, Iflik O (2002) Phytoplankton distribution, diversity and nutrients at the north-eastern Mediterranean coast of Turkey (Karatafl-Adana). Turk J Bot 26:77-86 
Polat S, Koray T (2002) New records of the genus Histioneis F.R von Stein (Dinophyceae) from Turkish coastal waters. Turk J Bot 26:481-484

Polat S, Koray T (2007) Planktonic dinoflagellates of the northern Levantine Basin, northeastern Mediterranean Sea. Eur J Protistol 43:193-204

Polat S, Sarihan E, Koray T (2000) Seasonal changes in the phytoplankton of the northeastern Mediterranean (Bay of İskenderun). Turk J Bot 24:1-12

Taylor FJR (1976) Dinoflagellates from the International Indian Ocean Expedition. Bibliotheca Botanica 132:1-234

Vesk M, Lucas IAN (1986) The rhabdosome: a new type of organelle in the dinoflagellate Dinophysis. Protoplasma 134:62-64

Editorial responsibility: Robert Sanders,

Philadelphia, Pennsylvania, USA
Viliãiç D, Marasoviç I, Miokoviç D (2002) Checklist of phytoplankton in the eastern Adriatic Sea. Acta Bot Croat 61: 57-91

Wood EJF (1954) Dinoflagellates in the Australian region. Aust J Mar Freshw Res 5:171-352

Wood EJF (1963a) Check-list of dinoflagellates recorded from the Indian Ocean. CSIRO Div Fish Oceanogr Rep No. 28. CSIRO, Sydney

Wood EJF (1963b) Dinoflagellates in the Australian region. II. Recent collections. CSIRO Div Fish Oceanogr Tech Pap No. 14. CSIRO, Melbourne

Wood EJF (1963c) Dinoflagellates in the Australian region. III. Further collections. CSIRO Div Fish Oceanogr Tech Pap No. 17. CSIRO, Melbourne

Submitted: January 13, 2009; Accepted: July 13, 2009

Proofs received from author(s): November 15, 2009 